University of Wollongong

Research Online

Faculty of Engineering and Information

Faculty of Engineering and Information

Sciences - Papers: Part B

Sciences

2020

Extraction of strategically important elements from brines: Constraints and opportunities

Biplob K. Pramanik

Royal Melbourne Institute of Technology, biplobkp@uow.edu.au

Long D. Nghiem

University of Technology Sydney, Nguyen Tat Thanh University, longn@uow.edu.au

Faisal I. Hai

University of Wollongong, faisal@uow.edu.au

Follow this and additional works at: https://ro.uow.edu.au/eispapers1

Part of the Engineering Commons, and the Science and Technology Studies Commons

Research Online is the open access institutional repository for the University of Wollongong. For further information contact the UOW Library: research-pubs@uow.edu.au 


\title{
Extraction of strategically important elements from brines: Constraints and opportunities
}

\author{
Abstract \\ Strategically important elements are those that are vital to advanced manufacturing, low carbon \\ technologies and other growing industries. Ongoing depletion and supply risks to these elements are a \\ critical concern, and thus, recovery of these elements from low-grade ores and brines has generated \\ significant interest worldwide. Among the strategically important elements, this paper focuses on rare \\ earth elements (REEs), the platinum-group metals and lithium due to their wide application in the \\ advanced industrial economics. We critically review the current methods such as precipitation, ion \\ exchange and solvent extraction for extracting these elements from low-grade ores and brines and \\ provide insight into the technical challenges to the practical realisation of metal extraction from these \\ low-grade sources. The challenges include the low concentration of the target elements in brines and \\ inadequate selectivity of the existing methods. This review also critically analyzes the potential \\ applicability of an integrated clean water production and metal extraction process based on conventional \\ pressure-driven membrane and emerging membrane technologies (e.g., membrane distillation). Such a \\ process can first enrich the strategically important elements in solution for their subsequent recovery \\ along with clean water production.

\section{Disciplines} \\ Engineering | Science and Technology Studies

\section{Publication Details} \\ Pramanik, B. Kumar., Nghiem, L. Duc. \& Hai, F. I. (2020). Extraction of strategically important elements \\ from brines: Constraints and opportunities. Water Research, 168 115149-1-115149-13.
}




\section{Research Highlight}

* Recovery of strategically important elements from brines is reviewed.

* Challenges associated with separation processes for metal extraction are discussed

* Membrane distillation is effective to recover strategically important elements

* Critical challenge associated with membrane processes is fouling. 


\section{Extraction of strategically important elements from brines: constraints and} opportunities

\section{Biplob Kumar Pramanik ${ }^{a}$, Long Duc Nghiemb and Faisal I. Hai}

${ }^{a}$ Civil and Infrastructure Engineering Discipline, School of Engineering, RMIT University,

$$
\text { VIC 3001, Australia }
$$

${ }^{\mathrm{b} C e n t r e}$ for Technology in Water and Wastewater, School of Civil and Environmental Engineering, University of Technology Sydney, Sydney, NWS 2007, Australia.

'Strategic Water Infrastructure Laboratory, School of Civil, Mining and Environmental Engineering, University of Wollongong, Wollongong, NSW 2522, Australia.

Corresponding author Email: biplob.pramanik@rmit.edu.au; Tel: +6139925 9419

Revised manuscript submitted to Water Research 


\begin{abstract}
Strategically important elements are those that are vital to advanced manufacturing, low carbon technologies and other growing industries. Ongoing depletion and supply risks to these elements are a critical concern, and thus, recovery of these elements from low-grade ores and brines has generated significant interest worldwide. Among the strategically important elements, this paper focuses on rare earth elements (REEs), the platinum-group metals and lithium due to their wide application in the advanced industrial economics. We critically review the current methods such as precipitation, ion exchange and solvent extraction for extracting these elements from low-grade ores and brines and provide insight into the technical challenges to the practical realisation of metal extraction from these lowgrade sources. The challenges include the low concentration of the target elements in brines and inadequate selectivity of the existing methods. This review also critically analyzes the potential applicability of an integrated clean water production and metal extraction process based on conventional pressure-driven membrane and emerging membrane technologies (e.g., membrane distillation). Such a process can first enrich the strategically important elements in solution for their subsequent recovery along with clean water production.
\end{abstract}

Keywords: Strategically important elements, challenges, low-grade ores and brines, emerging membrane process. 


\section{Introduction}

Recent technological advances are mostly based on innovative applications of a range of rare metals and metalloids into intelligent and high-tech devices. Examples include rare earth metals (e.g., cerium, lanthanum, neodymium, dysprosium, praseodymium, scandium, erbium, europium, terbium and yttrium), precious metals (e.g., rhodium, palladium, and platinum), radioactive metals (e.g. uranium and radium) and alkaline metals (e.g., magnesium, potassium, and lithium). These elements are indispensable in the electronic and electrical industries (Alonso et al., 2012), making them some of the most valuable non-renewable resources for our modern society. For example, the production of a smartphone requires a range of rare earth metals including neodymium, gadolinium and samarium along with others metals, such as lithium, indium, palladium, tantalum, silver, gold, copper, gallium, germanium, beryllium, and zirconium (Tanskanen, 2013). However, increasing depletion of some of these elements has been revealed as a major risk to viable economic development.

To date, most metals are produced from hard-rock mining. During the last two decades, advances in water purification (e.g., desalination) and resource recovery have led to the concept of seawater and brine being perceived as important untapped sources of precious and rare earth elements (Bardi, 2010; Gibert et al., 2010; Lee et al., 2013; Saito et al., 2006). It is also notable that these elements can cause severe environmental pollution due to their toxicity. Thus, the challenge to conserve these rare metals and metalloids and to protect the environment has strategically spurred the need to extract and recover them from complex solutions.

The main technologies used for producing metals from low-grade ores and brines are based on precipitation, ion exchange and hydrometallurgical processes. The ion exchange process is 
a selective process which requires a specific resin to recover valuable metals selectively. Hydrometallurgical treatments are based on the use of leaching agents in aqueous solutions such as strong acids and bases. These are often applied together with other complexing agents such as oxalic acid, cyanide, halide, acetic acid and thiosulfate (Beolchini et al., 2010). Given the techno-economic analysis, the technological challenges of the mentioned processes and the low levels of elements concentration have received attention. Hence, a cost-effective, low energy consuming and greener-recycling process needs to be developed to handle the challenges associated with next-generation metal demand and to conserve natural resources. Membrane-based technologies may provide a viable solution for efficient recovery of rare earth elements from brine as these processes can easily enrich the elements effectively.

This article critically discusses the opportunities and challenges of strategically important element recovery from low-grade ore and brine solution using conventional and emerging technologies. In terms of the strategically important elements, this paper focuses on the extraction of rare earth elements (REEs), the platinum-group metals and lithium due to their wide application in the advanced industrial economics. We conclude this article by providing an outlook of the opportunities for the separation of strategically important elements using integrated conventional and emerging membrane-based technologies. Wherever available, information on pilot or full-scale facilities in addition to lab-scale studies has been systematically presented. Information on the technology readiness level and economic feasibility is a notable gap in the literature. 


\section{Strategically important elements}

A range of chemical elements is strategically important to modern life. Indeed, they are essential in many everyday products ranging from mobile phones to automobiles. The emerging renewable energy market also utilises many of these elements (Figure 1). Among them, three of the most notable groups are rare earth elements (REEs), the platinum-group metals, and lithium. Although the application of these elements is often not well known to the general public unfamiliar with the industrial processes, the current rate of consumption of many of these strategically important elements is not sustainable.

REEs are probably the strategically important elements of the most critical concern, given their applications in emerging technologies including fuel cells and wind turbines (Figure 1) but uncertain future supplies. Over $500 \mathrm{~kg}$ of REEs including neodymium, molybdenum, and dysprosium (Figure 1) are required to make the permanent magnets in a single 3.5 MW wind turbine (Constantinides, 2016). Since the growth in wind power markets is expected to continue, the demand for neodymium magnets $(\mathrm{NdFeB})$ in wind turbines in 2020 is expected to be increased to approximately 13.2 kilotons, which is about 1.7 times higher compared to the NdFeB amount required in 2015 (Pavel et al., 2017). If magnet composition remains invariable, about 3.2 kilotons of neodymium, 0.8 kilotons of praseodymium and 0.93 kilotons of dysprosium would be requested by the global wind power sector in 2020. This is equivalent to $15 \%, 13 \%$ and $66 \%$ of the total production of neodymium, praseodymium and dysprosium, respectively in 2014 (Pavel et al., 2017). A NdFeB magnet now incorporates 29$32 \%$ neodymium/praseodymium, which might decrease to $25 \%$ by 2020 and even further to 20\% by 2030 (Lacal-Arántegui, 2015). Instead of using magnets with 3-6\% dysprosium, newer generator models can use permanent magnets with only about $1 \%$ dysprosium. Pathak et al. (2015) claim to have developed a new way to replace dysprosium fully and neodymium 
partly (by about 20\%) in the $\mathrm{NdFeB}$ magnet using cobalt and cerium (much cheaper and more available REE). The cerium and cobalt co-doped alloy shows excellent hightemperature magnetic properties. Terbium can replace dysprosium in a NdFeB magnet, but it is not considered a convenient substitute today. If terbium becomes cheaper than dysprosium, e.g. due to decreasing terbium demand in lighting (Pavel et al., 2016), it could be used as a substitute for some quantities of dysprosium in magnet applications.

Currently the world reserves of REEs in major countries such as China, Brazil, Vietnam, Russia and India stand at about 130 million tonnes (USGS, 2019). It is noted that the REEs reserve is not uniformly distributed globally. Most of the confirmed REE reserve is in China, which produces $85 \%$ of the global REEs output (Roskill, 2015). The current annual global production of REEs is about 120 kilotons (Izatt et al., 2016), yet the demand for REEs is expected to grow further as the renewable and electronic industries continue to expand. The annual growth rate of global REE demand is estimated to be about 5\% (USGS, 2016). A similar prediction was made by Dutta et al. (2016) who noted that global REE demand is slated to grow at an annual rate of $5 \%$ by 2020 . Graede (2015) indicated that there would be scarcity and supply risk for europium, dysprosium and erbium in addition to several other metals in the near future. This estimation is based on their scores in three areas, namely supply risk, environmental implications, and vulnerability to supply restrictions. Hence, the global availability of REEs appears to be at substantial risk for several reasons. These include the introduction of production quotas, export quotas and export taxes, enforced environmental legislation, and granting no new rare earth mining licenses (USGS, 2019). As a result, there has been increased interest and investigation into non-traditional REE resources, extraction, separation and purification processes. 
The demand for platinum-group elements is likely to increase due to increasing demand for vehicles globally in the forthcoming decades. In 2016, the automobile industry continued to be the major consumer of platinum-group elements which accounted for approximately $84 \%$ of global rhodium consumption, $67 \%$ of palladium consumption and $46 \%$ of platinum consumption (CPM Group, 2017). Loferski (2011) noted that each year, the automobile industry alone uses 113 tons of platinum and other platinum-group metals as catalysts for air pollution control. Jollie (2017) predicts compound annual growth rates (CAGRs) of total platinum and palladium demand of 1.0 and 1.1\%, respectively. An economic model by Zhang et al. (2016) shows a growth in the demand for platinum and palladium of approximately 5\% and $45 \%$, respectively over the next 15 years. This growth in demand for the platinum-group metals is driven largely by the increasing automobile sales, particularly in emerging markets such as China and India. The platinum-group metals are also essential for catalytic conversion in fuel cells. Thus, an even more significant increase in the demand for these metals is expected if fuel cell automobiles can be mass-produced in the future (Wittstock et al., 2016).

The current recoverable reserve of platinum-group metals of about 100 kilotons is geographically unevenly distributed. South Africa has about $80 \%$ of the global reserve of platinum-group metals and the remaining is in Russia (8\%) and Zimbabwe (7\%) (IDC, 2013). Notably, most of the world's supply of platinum-group elements comes from South Africa and Russia, which account for 56\% and 24\%, respectively, of the global production (USGS, 2019). The total worldwide supply in 2013 was 187.9 tons for platinum, 206.7 tons for palladium, and 22.1 tons for rhodium (Johnson, 2014). In comparison, the supply of platinum-group elements in 2000 was 153 tons for platinum, 224 tons for palladium and 20.9 tons for rhodium (Johnson, 2001). This reflects the growing worldwide use of platinum-group 
elements. By contrast, Thormann et al. (2017) reported that the global platinum and palladium production decreased by $25 \%$ and 8\%, respectively from 2010 to 2014. The decline observed throughout this period was mainly due to a consequence of the strikes in South Africa. According to Thormann et al. (2017), future estimates of demand, production and recycling, based on CAGRs of $0.4,1.7$ and 3.3\% for primary production, recycling and demand of platinum, respectively, indicate a supply gap in the near future. The competition to obtain these elements has also led to geopolitical tension and instability.

Lithium is another notable strategically important element that is essential for rechargeable batteries (Figure 1). Due to the recent boom in the renewable energy industry and electric vehicles, lithium consumption for batteries has increased significantly in recent years. Lithium demand is expected to grow faster than supply in the coming decade. Martin et al. (2017) estimate an annual increase in lithium demand of 9\% over the next 3 years.
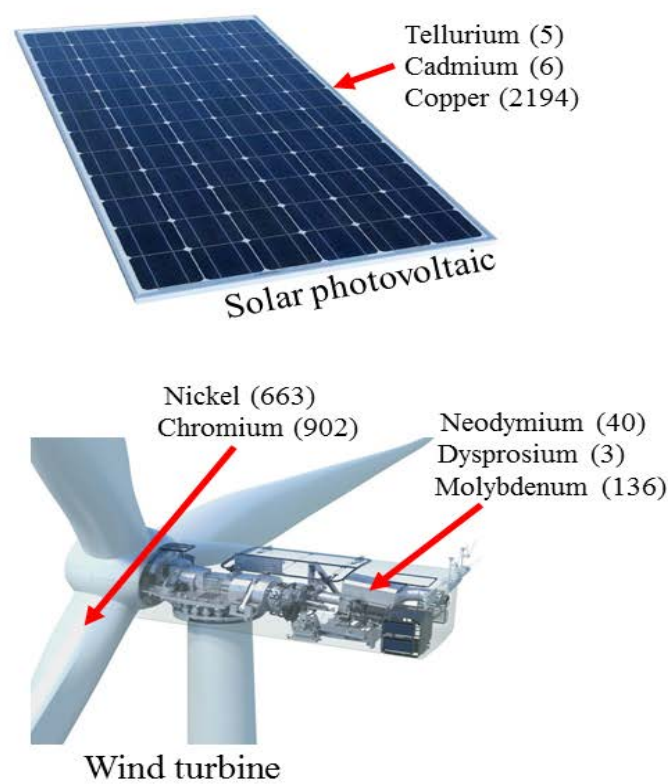



Lithium-ion battery

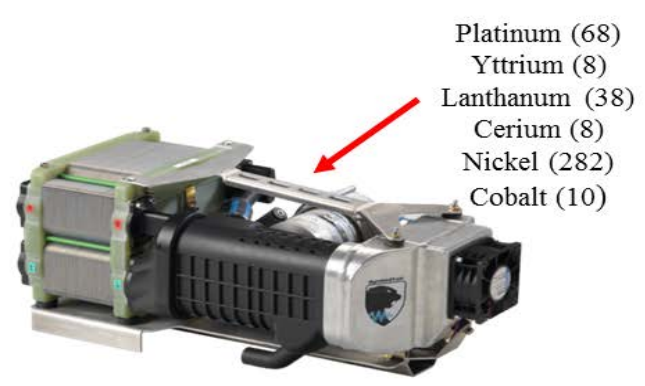

Fuel cell

Figure 1: Examples of strategically important element demand (kg/MW) in the renewable energy industry (Moss et al., 2011; Moss et al., 2013; Teske et al., 2016). 
The supply security of strategically important elements to support our modern society depends not only on their geological deposits but also the availability of separation technologies for their extraction. The latter is particularly important in the context of the future circular economy when these elements are sourced from consumer products at the end of their lifetime rather than geological deposits. As a major exporter of many minerals, Australia is a notable example of the interplay between the availability of geological deposits and separation technologies. Australia provides $8 \%$ of the global REEs production (Skirrow et al., 2013) despite having a rather modest reserve of these elements. Australia is currently the world largest lithium producer with $34 \%$ of the global production (Table 1). Yet, in terms of geological availability of lithium, Australia is only ranked fourth in the world after China, Argentina, and Chile (USGS, 2016). It is noteworthy that Australia has many salt lakes and saline groundwater deposits that contain a range of strategically important elements (Timms, 2005).

In the current hydrometallurgical industry, processes for the separation/ extraction of strategically important elements are precipitation, ion exchange and solvent extraction. A major challenge of these processes is separation selectivity (Izatt et al., 2016). Hence, a pragmatic approach is important to recover these strategically important elements from lowgrade sources including salt lake brines. 
Table 1: The production, resources and reserve status of some prospective elements in Australia and their application for different purposes

\begin{tabular}{|c|c|c|c|c|c|c|c|}
\hline \multirow[t]{2}{*}{ Metals } & \multicolumn{2}{|c|}{ Production } & \multicolumn{2}{|c|}{ Resource } & \multicolumn{2}{|c|}{ Reserve } & \multirow[t]{2}{*}{ Applications } \\
\hline & $\begin{array}{c}\text { Mass } \\
\text { (kt) }\end{array}$ & $\begin{array}{c}\text { Global share } \\
(\%)\end{array}$ & $\begin{array}{c}\text { Mass } \\
(\mathbf{k t})\end{array}$ & $\begin{array}{l}\text { Global share } \\
\text { (\%) }\end{array}$ & $\begin{array}{c}\text { Mass } \\
(\mathbf{k t})\end{array}$ & $\begin{array}{l}\text { Global share } \\
(\%)\end{array}$ & \\
\hline Cerium & 7.6 & 8 & 1481 & 3 & $\mathrm{NA}$ & 2.8 & $\begin{array}{l}\text { Catalytic converters in cars, hybrid vehicles, television } \\
\text { faceplates, silicon microprocessors. }\end{array}$ \\
\hline Lanthanum & 4.6 & 8 & 742 & 3 & NA & 2.8 & $\begin{array}{l}\text { Cracking catalysts in petroleum refining, camera lenses, } \\
\text { battery electrodes, hydrogen storage, x-ray films. }\end{array}$ \\
\hline Dysprosium & 0.115 & 4.8 & NA & NA & 8 & 0.64 & $\begin{array}{l}\text { Motors or generators, wind turbines, and electrical } \\
\text { vehicles, hard disk devices, transducers. }\end{array}$ \\
\hline Yttrium & NA & NA & 100 & 18.5 & NA & NA & $\begin{array}{l}\text { Microwave generators, televisions and computer } \\
\text { screens, ceramics, superconductors. }\end{array}$ \\
\hline Platinum & 0.22 & 0.11 & 2.35 & 1.2 & NA & NA & Catalytic converters, electronic application, fuel cells \\
\hline Palladium & 0.22 & 0.11 & 2.35 & 1.1 & NA & NA & \\
\hline Lithium & 11.7 & 34 & 1006 & 8 & 1500 & 10.7 & Electric batteries, cordless devices, ceramics, glass. \\
\hline
\end{tabular}

$4 \quad$ NA: Not available 
6 3. Key challenges associated with separation processes for strategically important

7 elements recovery

Low concentration and co-occurrence with other elements of much higher concentration, processing cost and environmental impacts are major challenges to the cost-effective recovery of strategically important elements from low-grade ores and brines. The significance of these challenges depends on the source of brine. The high amount of water and energy consumed in producing these elements also makes the separation process inefficient.

Strategically important elements often occur at low concentrations in low-grade ores and brines, and, thus, are difficult to recover in the presence of much higher concentrations of other minerals which can interfere with the separation and enrichment process. Hu et al. (2018) noted that the selective extraction of scandium was limited by the presence of other REEs, aluminium and iron. Similarly Barros et al. (2019) reported that the recovery of REE was affected by the competition of other base metals present in the brine solution. Callura et al. (2018) noted that the presence of competing ions (calcium, magnesium, zinc, iron and aluminium) could inhibit the complete recovery of REEs. The undesired elements such as phosphate, iron, aluminium, nickel, chromium, manganese, zirconium, uranium and copper were first separated to reduce the impurities during REEs recovery in a week acidic medium using oxalic acid (El-Awady, 2013). Safarzadeh et al. (2018) noted that nickel, copper and cobalt need to be removed to achieve $99.9 \%$ purity of platinum group elements. SepraMet is a metal refinery located in Houston, Texas, which features the use of molecular recognition technology-hydrometallurgical processes in the selective recovery of platinum group elements from low-grade ores (Izatt et al., 2015). They noted that the unwanted or deleterious elements such as arsenic, iron and antimony need to be separated effectively for the target platinum group elements recovery. 
32 The level of lithium (0.06-1.21 g/L) in brine can be significantly low compared to magnesium ion (3.4-113.7 g/L) (Table 2). The extraction efficiency of lithium depends on the magnesium to lithium mass ratio (Table 2). A low magnesium to lithium ( $\mathrm{Mg} / \mathrm{Li})$ ratio in brine means that it is easier, and therefore more economical to extract lithium. Zhao et al. (2013) noted that when the $\mathrm{Mg} / \mathrm{Li}$ ratio is below 6, lithium can be effectively separated by chemical precipitation method. However, the $\mathrm{Mg} / \mathrm{Li}$ ratio of most brines is higher than 6 (Table 2). Therefore, the use of an appropriate treatment process (e.g., nanofiltration) for avoiding their interference with the crystallisation of lithium carbonate is essential to remove magnesium ion.

Purity is an important parameter that is directly related to how strategically important elements can be used and their commercial value. For example, over 99.9\% purity of lithium carbonate is required for the production of lithium-ion batteries (Virolainen et al., 2016). On the other hand, lithium carbonate with purity below $99.6 \%$ can only be used for ceramic production (Virolainen et al., 2016).

Similar physiochemical properties of some strategically important elements can affect the separation of the target element. Most REEs occur together in mineral deposits and therefore separation of them from each other is quite difficult due to similar ionic radius and chemical properties (Cardoso et al., 2019). For example, related to the aforementioned example of separation of lithium from magnesium, magnesium too precipitates with lime as magnesium carbonate, which prevents the formation of lithium carbonate (Kogel, 2006). 
Table 2: Composition of lithium in salt lake brine around the world

\begin{tabular}{|c|c|c|c|c|c|c|c|c|c|c|}
\hline \multirow[t]{2}{*}{ Source } & \multirow[t]{2}{*}{ Status } & \multicolumn{7}{|c|}{ Concentration (g/L) } & \multirow{2}{*}{ Impurities } & \multirow[t]{2}{*}{ References } \\
\hline & & $\mathrm{Li}^{+}$ & $\mathrm{Mg}^{2+}$ & $\mathrm{Na}^{+}$ & $\mathrm{Ca}^{2+}$ & $\mathrm{K}^{+}$ & $\mathrm{B}$ & $\mathrm{SO}_{4}^{2-}$ & & \\
\hline $\begin{array}{l}\text { Atacama Salar } \\
\text { Brine, Chile }\end{array}$ & Full-scale & 3.02 & 17.6 & 61.9 & 0.41 & 28.2 & 1.72 & 37.9 & $\begin{array}{l}\mathrm{Na}^{+}, \mathrm{K}^{+} \\
\mathrm{Mg}^{2+}\end{array}$ & Ogawa et al. (2014) \\
\hline $\begin{array}{l}\text { Uyuni Salar } \\
\text { Brine, Bolivia }\end{array}$ & & 0.84 & 16.7 & 105.4 & 3.33 & 15.7 & 0.7 & 21.3 & $\mathrm{Na}^{+}, \mathrm{K}^{+}, \mathrm{B}$ & An et al. (2012) \\
\hline $\begin{array}{l}\text { East Taijinar, } \\
\text { China }\end{array}$ & Pilot-scale & 0.14 & 5.64 & 117.03 & 0.43 & 3.79 & - & - & $\mathrm{Na}^{+}, \mathrm{K}^{+}$ & Sun et al. (2015) \\
\hline $\begin{array}{l}\text { West Taijinar, } \\
\text { China }\end{array}$ & & 0.26 & 15.36 & 102.4 & 0.19 & 8.44 & - & - & $\mathrm{Na}^{+}, \mathrm{K}^{+}$, & Sun et al. (2015) \\
\hline $\begin{array}{l}\text { Chott Djerid Salt } \\
\text { Lake, Tunisia }\end{array}$ & & 0.06 & 3.4 & 80 & 1.6 & 5.6 & - & 6.7 & $\begin{array}{l}\mathrm{Na}^{+}, \mathrm{Ca}^{2+} \\
\mathrm{Mg}^{2+}\end{array}$ & $\begin{array}{l}\text { Somrani et al. } \\
\text { (2013) }\end{array}$ \\
\hline $\begin{array}{l}\text { Longmucuo, } \\
\text { China }\end{array}$ & & 1.21 & 89.5 & - & - & - & - & - & - & Song et al. (2017) \\
\hline $\begin{array}{l}\text { North Arm Salt } \\
\text { Lake, USA }\end{array}$ & Lab-scale & 0.04 & 9.38 & 100.8 & 0.35 & 5.5 & 0.03 & 19.7 & $\mathrm{Na}^{+}$ & Bush et al. (2016) \\
\hline $\begin{array}{l}\text { Salt lake brine, } \\
\text { China }\end{array}$ & & 0.35 & 113.7 & - & - & - & - & - & $\mathrm{Mg}^{2+}$ & Xiang et al. (2016) \\
\hline Salt lake brine & & 0.15 & 8.88 & 2.69 & - & - & - & - & - & Ji et al. (2017) \\
\hline Geothermal brine & & 0.01 & - & 0.11 & - & 0.16 & 0.03 & - & $\mathrm{K}^{+}$ & $\begin{array}{l}\text { Mroczek et al. } \\
\text { (2015) }\end{array}$ \\
\hline Synthetic brine & & 0.15 & 63.8 & 0.414 & 0.02 & 0.20 & & - & $\mathrm{Mg}^{2+}$ & Nie et al. (2017b) \\
\hline
\end{tabular}


The cost of the recovery process is an important consideration for the industry. The process can be very expensive when multiple steps are required for the separation of these elements. For example, lithium-losses are typically more than $10 \%$ in the multiple separation steps (Virolainen et al., 2016). Solvent loss during multiple solvent extraction steps can make an extraction process further uneconomical. For example, using solvent extraction for the separation of niobium and tantalum, evaporation loss of the solvent (i.e., hydrofluoric acid) alone was 6-7\% (Wang et al., 2010). Multiple separation steps also produce large amounts of secondary chemical waste resulting in high costs associated with their disposal.

Separation processes used for the recovery of strategically important elements often raise environmental concerns. For example, the use of large volume of organic solvents for the recovery of these elements has an adverse environmental impact. This is because organic solvents are toxic, corrosive, inherently volatile and flammable (Nishihama et al., 2003). Their volatility and solubility contributes to air, land and water pollution. Yang et al. (2013) noted that mining and production processes in China have resulted in the creation of large polluted areas, which are now attracting international attention. Every ton of rare earth metal produced generates approximately 8.5 kilograms of fluorine, 13 kilograms of dust, about 75 cubic meters of acidic wastewater and approximately 1 ton of radioactive waste residue (Hurst, 2010). Tharumarajah and Koltun (2011) conducted life cycle assessment (LCA) on Bayan Obo deposit in China to determine the equivalent greenhouse gas (GHG) emissions for production for rare earth oxides (REOs). Their analysis shows that the production of samarium, europium and gadolinium oxides emits approximately $55 \mathrm{~kg}$ of $\mathrm{CO}_{2}$ equivalent per $\mathrm{kg}$ of oxide produced, which is significantly higher than for iron $\left(0.02 \mathrm{~kg}\right.$ of $\mathrm{CO}_{2}$ equivalent) and copper (0.63 $\mathrm{kg}$ of $\mathrm{CO}_{2}$ equivalent (Norgate and Haque, 2010). In a follow up study, Koltun and Tharumarajah (2014) found that GHG emissions for light REOs 
84 (lanthanum-, cerium-, praseodymium-oxide) were $32.29 \mathrm{~kg} \mathrm{CO}_{2}$ equivalent per $\mathrm{kg}$ of REO, medium REOs (neodymium-, promethium-, samarium-oxide) were $30.29 \mathrm{~kg} \mathrm{CO}$ equivalent per kg of REO and heavy REOs (gadolinium-, yttrium- lutetium and scandium-oxide) were $34.49 \mathrm{~kg} \mathrm{CO} 2$ equivalent per $\mathrm{kg}$ of REO.

\section{Current separation processes for strategically important elements recovery}

Various separation processes have been used to extract strategically important elements from low-grade ores and brines. Traditional technology to extract these elements relies on subtle differences in their thermodynamic behaviors in the aqueous phase through a series of precipitation and crystallization steps (Bernardis et al., 2005). The process to recover lithium from the Uyuni Salar brine in Bolivia is shown in Figure 2 as an example. The Salar is a salt surface crust overlying brine saturated sediment. Following the removal of calcium, magnesium and boron, the concentrated brine can then be purified to remove other residual impurities such as sodium, sulphate and chlorine (An et al., 2012). The lithium concentrate is then subjected to carbonation for the precipitation of lithium carbonate with high purity (99.6\%).

Platinum-group metals and REEs are mainly recovered from the ore concentrate through acid leaching. Target elements from the leach solution are then separated by ion exchange or solvent extraction processes. For example, the ion exchange process has been used for the separation of platinum-group metals from the low-grade waste stream at Impala Refineries in Springs, South Africa (Figure 3). The concentrate contains about 65\% platinum-group metals (Crundwell, 2011). In this full-scale refinery plant, ion exchange, distillation and hydrolysis have been used to separate the individual platinum-group metals from the leach solution. Another industrial process for the recovery of strategically important elements is solvent extraction. In the Alwaye Plant in India, the separation of individual REEs from rare earth 
110 (Figure 4). In this process, the feed solution containing rare earth nitrate is produced during

111 the chemical treatment of monazite ore.

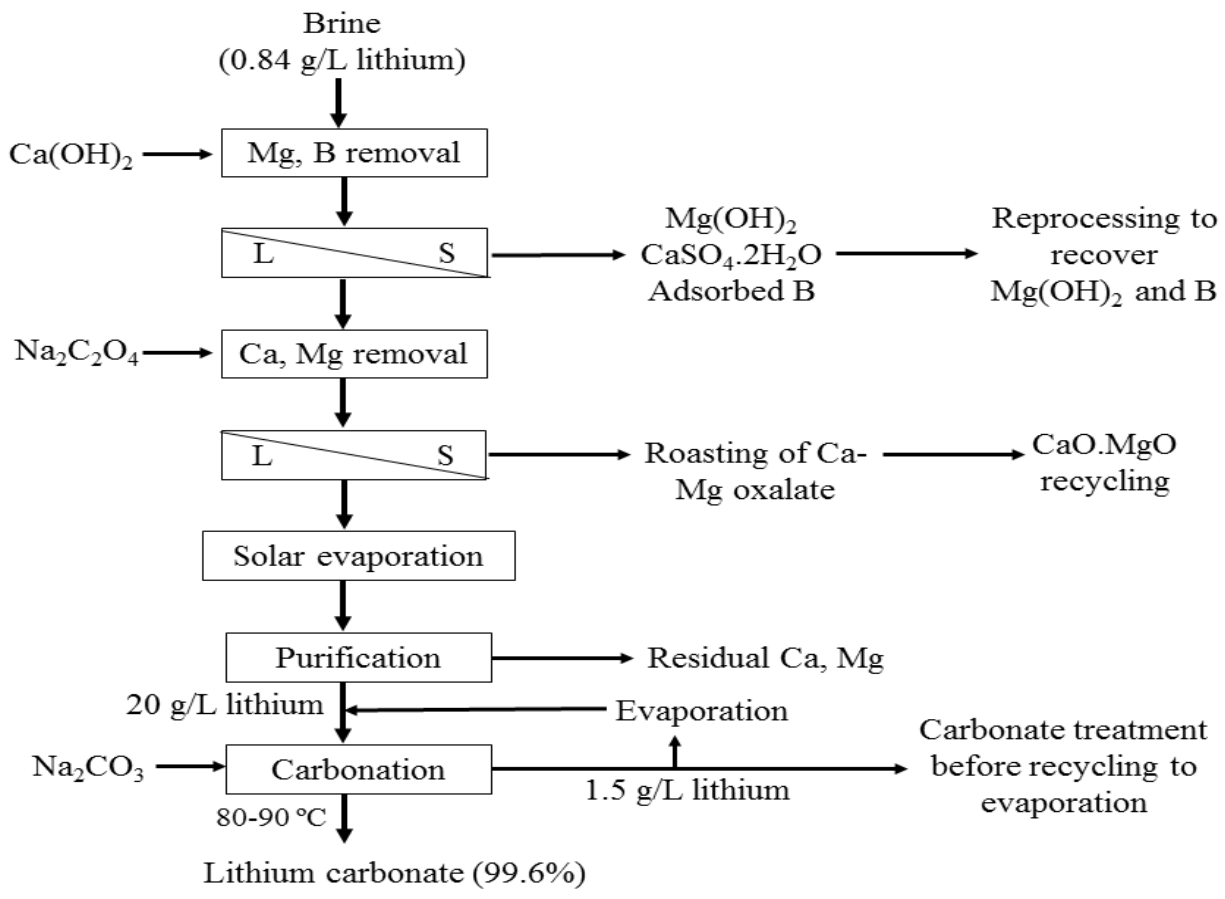

114 Figure 2: Flowsheet for the recovery of lithium as carbonate from Uyuni Salar brine, Bolivia

(An et al., 2012) 
Platinum-group metal concentrates

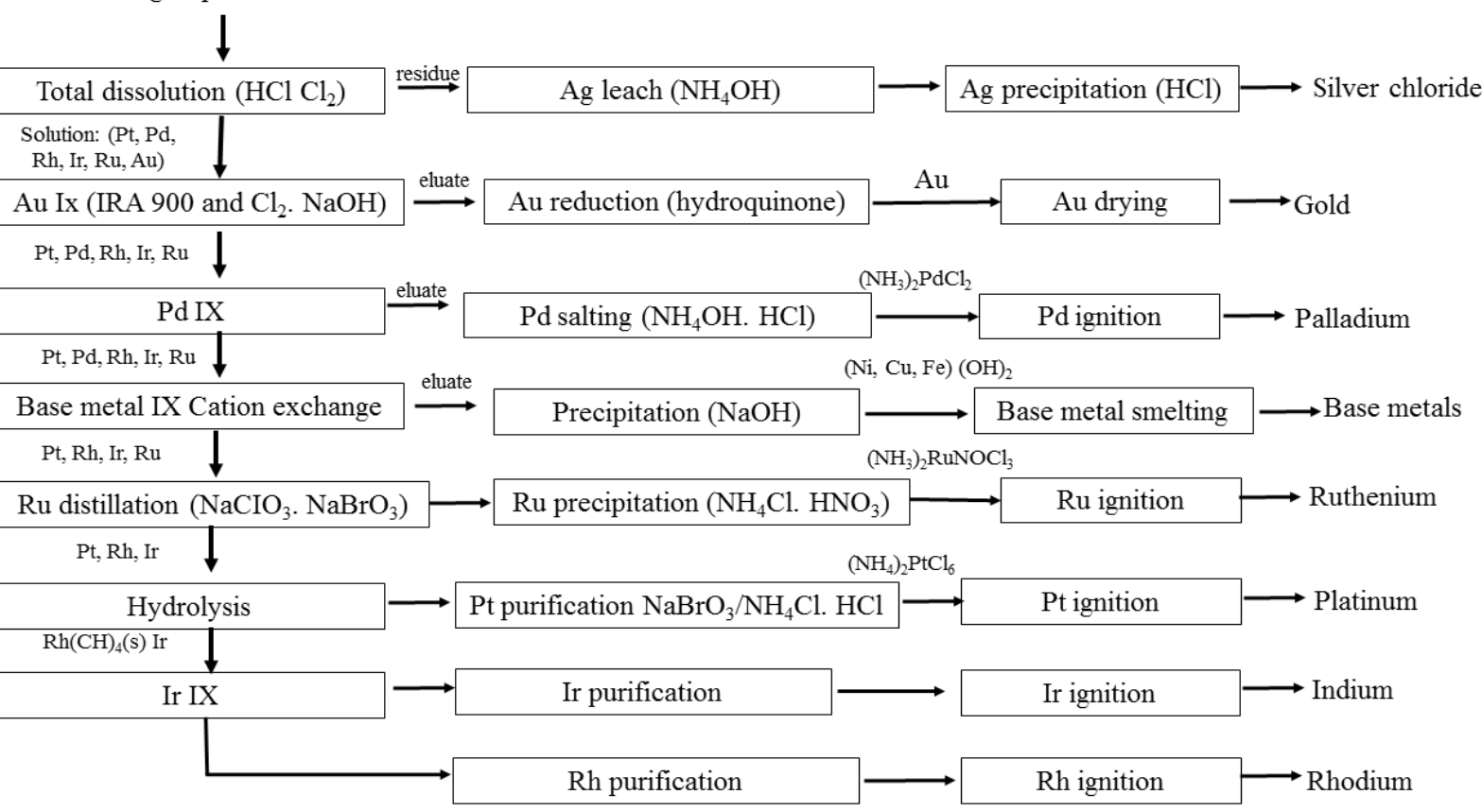

Figure 3: Platinum-group metals and other precious metal recovery using ion exchange process at Springs, South Africa (Crundwell, 2011).

Rare earth nitrate feed

(lanthanum, praseodymium, neodymium

and samarium)

$\downarrow$

Pure TBP $\longrightarrow$ Solvent extraction $\longrightarrow$ Raffinate: lanthanum, praseodymium

Neodymium and samarium

Pure TBP $\longrightarrow \begin{gathered}\text { Solvent extraction } \\ \text { (neodymium/samarium)/stripping }\end{gathered} \longrightarrow$ Samarium

122 Figure 4: Flowsheet of rare earth separations by solvent extraction at Alwaye Plant of Indian 


\subsection{Precipitation}

Precipitation is commonly used to separate strategically important elements from brines. For example, precipitation of lithium in the form of lithium carbonate from a concentrated lithium solution has been reported previously (Nishihama et al., 2011). However, the high amount of lime consumption for the precipitation of co-occurring magnesium and loss of lithium by coprecipitation are major challenges for the application of precipitation process for lithium recovery (Chen et al., 2017). Lithium recovery in the form of lithium aluminate from Dead Sea brine and end brine (after potash production) has been reported by several researchers (Epstein et al., 1981; Pelly, 1978). Pelly (1978) achieved 90\% extraction efficiency of lithium aluminate from both Dead Sea brine and end brine. However, they found that higher temperature has an adverse effect on the extraction efficiency, and the best yield was achieved at room temperature (Pelly, 1978). Another study by Epstein et al. (1981) focused on lithium extraction from the Dead Sea brine by precipitation as lithium aluminate followed by liquid-liquid extraction to separate the lithium from aluminium. Notably, evaporationprecipitation process has been used as the industry standard commercial process for lithium production from brines (Kotsupalo et al., 2013; Li, X. et al., 2015; Paranthaman et al., 2017; Yang et al., 2018; Yi et al., 2018). The process has shown excellent performance for lithiumprecipitation and $\mathrm{Li} / \mathrm{Mg}$ separation (Liu et al., 2018). However, this process is mainly suitable to apply in areas with arid climate to have significant evaporation of the brine. Notably, brine lakes occur at high altitudes and in areas with low rainfall, which makes an evaporationprecipitation process an effective approach for lithium extraction. As an alternative attempt, using concentrated sulfuric acid, leached solution containing lithium was obtained from roasted Zimbabwean petalite ore concentrate, and then, lithium carbonate was precipitated by adding sodium carbonate (Sitando and Crouse, 2012). However, treatment of petalite by the 
leaching method requires highly concentrated acid (Sitando and Crouse, 2012), which raises safety and environmental concerns.

REEs can also be separated using acidic and alkaline precipitation processes. For example, after extraction of uranium in a pilot plant, the effluent containing sulphate solution was subjected to complete precipitation for recovering REEs at $\mathrm{pH} 9.3$ using ammonium hydroxide (Khawassek et al., 2015). REEs can be also separated in a weak acidic medium via precipitation using oxalic acid. The oxalate precipitate is free from undesired elements such as phosphate, iron, aluminium, nickel, chromium, manganese, zirconium, uranium and copper (El-Awady, 2013). However, precipitation with oxalic acid is an expensive process. Recovering this acid along with strategically important elements would result in substantial savings for the process (Krishnamurthy and Gupta, 2004).

Platinum-group metals can also be separated using precipitation process. Platinum is precipitated as ammonium hexachloroplatinate with ammonium chloride from the leached solution that is produced from an ore concentrate (Phetla et al., 2010). Palladium could be precipitated using ascorbic acid. Palladium was reported to be precipitated selectively with an increase in the ascorbic acid concentration, while the other elements such as ruthenium, rhodium and iron were hardly precipitated (Lee et al., 2000). The precipitation behaviour of the platinum-group metals from liquid waste in a sequential denitration process with formic acid was shown by Kondo and Kubota (1992). The precipitation of ruthenium and rhodium increased linearly with the increase in $\mathrm{pH}$ of the denitrated solution. Above $98 \%$ of ruthenium and rhodium could be recovered via precipitation at $\mathrm{pH}>7$. However, the precipitation of base metals along with platinum-group metals is a major challenge in this process. 


\subsection{Ion exchange}

175

176

177

Ion exchange is an efficient and commercially mature technology for the recovery of strategically important elements from low-grade sources. Some advantages of ion exchange process include simple design, applicability to dilute feeds, ability to achieve a high concentration factor and no loss of separation media to the environment. The shortcoming to ion exchange is that the method does not work well with concentrated feeds: the kinetics is usually slow, and depending on the separation agent used, selectivity can be limited. Generally, the economics of ion exchange is driven mostly by the cost of resin regeneration chemicals, which increases proportionally with the increase in concentration of dissolved salts in the brine samples. For example, ion exchange is more cost-effective when used to treat brine water with $\leq 1500 \mathrm{mg} / \mathrm{L}$ dissolved salts (Kentish and Stevens, 2001). It is also noted that at lower TDS, ion exchange is extremely attractive for its low capital and operational costs and high recovery (90-95\%) rates (Aral et al., 2009). Ion exchange offers high separation efficiency of Li from brines, but the application of this method is limited in the large scale owing to the low loading capacity of resins (Al-Obaidani et al., 2008; Zhang et al., 2010).

Previous studies report that ion exchange could effectively recover platinum-group metals (Blokhin et al., 2009; Katsutoshi et al., 2008; Peng et al., 2009). In the metal industry, Smopex ${ }^{\circledR}$, SuperLig ${ }^{\circledR}$ and Amberlite IRA-93 materials are widely known as effective ion exchange resins for the recovery of platinum-group metals (Hubicki et al., 2008; Yahorava and Kotze, 2014). However, high cost and slow adsorption kinetics are the major limitations of these resins. Ion exchange has been used to recover platinum group elements from brine solution. Sun et al. (2012) investigated the performance of AG1-x8 resin to separate platinum and Rhodium from mixed chloride solution. They found that AG1-x8 could effectively 
separate platinum and rhodium. Nikoloski et al. (2015) used three ion exchange resins of different functional groups for the simultaneous recovery of platinum and palladium present in chloride solution. The tested resins included a resin with a quaternary ammonium functional group (Lewatit MonoPlus MP 600), a resin with a polyamine functional group (Purolite S985) and a resin with a thiouronium functional group (XUS 43600.00). They found that, among the investigated resins, XUS 43600.00 was the best resin to recover platinum and palladium chloride complexes. The recovery of platinum-group elements using Lewatit MP 600 WS and Purolite S985 anion exchangers were extensively studied by several researchers (Kononova et al., 2010; Kononova et al., 2011; Mel'nikov et al., 2012). These anion exchangers showed high sorption and kinetic properties for platinum-group elements recovery from synthetic brine. XUS 43600.00 with thiouronium functional group showed high selectivity for platinum group elements recovery (Nikoloski et al., 2015), but no data is readily available about the use of thiouronium functionalised resin in the simultaneous recovery of platinum, palladium and rhodium from brine solutions.

Lithium can also be recovered by ion exchange from brines. Hui (2000) reported that the $\mathrm{H}_{2} \mathrm{TiO}_{3}$ ion exchange resin could recover lithium from a brine of natural gas wells. The $\mathrm{H}_{2} \mathrm{TiO}_{3}$ ion exchanger has high selectivity for lithium with an exchange capacity of $25.34 \mathrm{mg}$ Lithium/g. In another study by Chitrakar et al. (2014), $\mathrm{H}_{2} \mathrm{TiO}_{3}$ ion exchanger achieved similar lithium adsorption capacity during the treatment of salt lake brine. Nishihama et al. (2011) have noted a selective recovery of lithium from seawater brine using two successive processes of ion exchange. Firstly, they used $\mathrm{k}-\mathrm{MnO}_{2}$ adsorbent to concentrate lithium followed by the purification of lithium from concentrated solution by a combination of acidic cation exchange resin to remove divalent metal ions and b-diketone/TOPO-impregnated resin to remove sodium and potassium. Finally, the recovery of lithium as precipitates of lithium 
carbonate was achieved using a saturated solution of ammonium carbonate. By this process, the lithium yield was 56\% and purity was 99.9\% (Nishihama et al., 2011). The recovery of lithium from seawater using IX type manganese oxide adsorbent has also been reported in

227

Korea (Liu et al., 2015). They noted that manganese oxide ion sieves could be considered as the most promising process for industrial application. Park et al. (2015) demonstrated that HMnO could be effectively used for recovery of lithium from seawater with good selectivity. Zandevakili et al. (2014) found more than 90\% lithium recovery from Urmia Lake by $\mathrm{MnO}_{2}$ ion-sieve. Bukowsky et al. (1991) have studied 3 different ion exchange resin (MC50, TP207, Y80-N) for recovery of lithium from synthetic brine containing higher contents of $\mathrm{CaCl}_{2}$ and $\mathrm{MgCl}_{2}$. They found that resin Y80-N at room temperature and the resin TP207 at $50{ }^{\circ} \mathrm{C}$ can be feasible to recover lithium chloride. Fukuda (2019) tested thirty IX resins in lithium chloride solution. They found that out of the thirty, sulfonate, iminodiacetate and aminomethylphosphonate resins could achieve lithium extraction capacity with the value of 16.3-32.9 mg-Li/g. However, none of the resins could adsorb lithium from a real brine solution effectively as a much higher concentration of sodium, potassium, calcium and magnesium ions are present (sometimes 100 times as high as lithium concentration), and these ions have a higher affinity to cation exchange resins (Fukuda, 2019). Thus, sodium and potassium can be partially recovered via evaporation as chloride salts, and magnesium and calcium can be precipitated as carbonates by soda ash before the lithium concentration gets high enough to be co-precipitated as a carbonate. Despite the unfavourable conditions for ion exchange resins with interfering ions, Dow Chemical (USA) introduced aluminium-loaded resins which is claimed to extract lithium selectively from brine, although this approach remains to be practically implemented (Fukuda, 2019). 
Separation of REEs into their individual components as part of the Manhattan Project during

World War II was a notable achievement of the ion exchange process (Izatt et al., 2014).

Subsequent development of chelating resins was a significant advancement in the application

251 of the ion exchange process for the recovery of metals. Chelating ion exchange resins adsorb metals through a combination of ionic and co-ordinating interactions rather than the simple electrostatic interactions in conventional ion exchange processes (Harland, 1994). Chelating ion exchange resins are regularly used in commercial systems to separate metal ions selectively. For example, neodymium is extracted from brine using the commercially available D113-III chelating resin (Xiong et al., 2011). Although this process is common for metal recovery in general, the efficacy of the process is yet to be demonstrated for some strategically important elements at industrial scale. Low concentration of the target elements in the solution in the presence of high concentrations of other interfering elements leads to slow recovery and high process cost.

\subsection{Solvent extraction}

The solvent extraction process has been used at commercial scale for the recovery of strategically important elements. This process is economically viable when the concentration of the target element is high (Kentish and Stevens, 2001). When the components of a mixture have similar physico-chemical properties the separation becomes difficult. In this process, separation and purification of REEs are made from the acidic/alkaline leaching solution containing impurities such as calcium, iron, aluminium and lead (Jha et al., 2016). Hence, the impurities affect the quality of the products formed and can be removed using precipitation process. Di-(2-ethylhexyl)phosphoric acid (D2EHPA) is widely used as a solvent extraction agent to recover REEs on an industrial scale (Jha et al., 2016). Studies found that D2EHPA could effectively separate high-grade europium, samarium gadolinium and scandium from 
other metals in a mixed nitrate-chloride leachate (Makanyire et al., 2016; Rabie, 2007).

274 Another study by Perez et al. (2019) shows that highest extraction rates were obtained using undiluted D2EHPA, especially for light REEs lanthanum (77.1\%) and cerium (94.9\%), while D2EHPA diluted in xylene provided the highest selectivity for terbium (heavy REE). Using a three-stage cross-current extraction, terbium was first recovered from the diluted methanesulfonic acid leachate with $100 \%$ selectivity and $97.5 \%$ recovery using $70 \% \mathrm{v} / \mathrm{v}$ D2EHPA in xylene (Perez et al., 2019). Afterwards, the remaining lanthanum and cerium from the diluted raffinate were recovered using three stages of extraction with undiluted D2EHPA with an efficiency of $98.8 \%$ for lanthanum and $100 \%$ for cerium (Perez et al., 2019). Studies have shown that neutral trialkyl phosphine oxides and tetraoctyl diglycol amide have the capability of extracting cerium and europium elements effectively (Larsson et al., 2012; Shimojo et al., 2008). Singh et al. (2008) reported that 2-ethylhexyl phosphoric acid-2-ethylhexyl ester (EHEHPA) could recover dysprosium with 98\% purity from concentrated $\mathrm{HCl}$ leaching solution. However, this separation required several stages due to the low separation factor (i.e., presence of competing ions). Wang et al. (2011) studied the performance of solvent extraction using a mixture of sec-octylphenoxy acetic acid and Cyanex272 for extraction of yttrium from other rare earth metals and reported high selectivity of yttrium. However, the presence of iron, manganese, and aluminium are the common impurities during extraction of these elements that affect the quality of products (Makanyire et al., 2016). Hence, this has led to the use of other processes such as selective precipitation to remove the metals competing for adsorption with the target metals. In this process, several elements are produced as a co-product/by-product. For example, REEs are recovered as a byproduct of uranium extraction at Denison Mines, Elliot Lake in Canada (Krishnamurthy and Gupta, 2004). 
The solvent extraction process is also employed to recover platinum-group elements from low-grade sources. Perez et al. (2019) investigated the separation of platinum and palladium from chloride solution by solvent extraction using Alamine 300 as an extractant. They found that platinum could be selectively extracted as the major component along with minor amounts of palladium using a saturated solution of sodium chloride at $\mathrm{pH}$ 1.5. This process could achieve a 99.9\% purity of platinum. Perez et al. (2019) also found a high palladium recovery (99.8\%) using a two-stage countercurrent extraction process with 0.5\% LIX 84I (2hydroxy-5-nonylacetophenone oxime). In their process, scrubbing using diluted $\mathrm{HCl}$ was done to remove the co-extracted base metal and resulted in platinum of $99.7 \%$ purity. The investigated by Reddy et al. (2010).

Previous studies report that solvent extraction with $\beta$-diketones and n-butanol can be used to extract lithium from brines. For example, Gabra and Torma (1978) established a lab-scale lithium chloride extraction process with n-butanol using synthetic solutions including different quantities of lithium, sodium chloride, potassium, and calcium chloride. They found that this process could recover lithium chloride with 99.6\% purity (Gabra and Torma, 1978). Shi et al. (2016) reported separation of lithium and magnesium from Salt Lake brine by liquid-liquid extraction with tributyl phosphate. They found that under the optimum conditions, the extraction efficiency of lithium was $80.64 \%$ and $99.42 \%$ by a single-stage and a three-stage countercurrent extraction, respectively. Recently, Pure Energy Minerals Inc has reported the results of preliminary pilot-scale tests by Tenova Advanced Technology and LiSXTM technology on the Clayton Valley Project, which showed great potential for largescale application of lithium extraction from brines using novel organic reagents including ketone, $\beta$-diketone, ionic liquids, and crown ethers (Energy, 2019). This process extracted 
323 lithium and separated sodium and potassium after calcium and magnesium removal.

324 However, these processes are still a long way from an industrial application due to technical and economic limitations. Shi et al. (2013) investigated a pilot-scale experiment for the recovery of lithium using TBP in N, N-di(2-ethylhexyl)acetamide/kerosene, and they observed the extraction efficiency of lithium to reach $96 \%$. This demonstrates that TBP is an effective extractant for lithium recovery from salt lake brines. However, as mentioned in Section 3, the high magnesium/lithium ratio in brine found in salt lakes is a challenge for large-scale lithium extraction.

The application of membrane in solvent extraction for the separation of strategically important elements has been investigated in the past (Kim et al., 2015; Xing et al., 2016). In this process, a membrane barrier, permeable to cations and impermeable to organic solvent, is located at the interface between the organic solvent and brine, thereby selectively extracting the strategically important elements. A membrane-assisted solvent extraction process for the recovery of REEs from nitric acid solutions was demonstrated by Kim et al. (2015). The system exhibited high selectivity for REE extraction without co-extraction of other elements. Xing et al. (2016) recently tested solvent stable hydrophilic nanoporous poly (ethylene-covinyl alcohol) membranes for lithium recovery. They observed a stable lithium extraction process for approximately 45 days, indicating the potential of this process for large-scale applications.

The conventional technologies have limitations in selectivity and efficiency in recovering metals from low-grade sources. It is also noteworthy that often these processes consume a huge amount of water during extracting metals. MacLean et al. (2009) estimated that mining and processing of metals utilise $0.03 \%$ of total world water. Given the scarcity of strategically 
important elements and clean water, a process that can concentrate metal salts for their extraction and produce clean water for reuse during the extraction process is highly warranted. In this context, the integration of a membrane process with conventional separation techniques could be a suitable approach (Marchetti et al., 2014; Székely et al., 2012). Membrane technology can provide better metal separation compared to conventional techniques (Chun-Te Lin and Livingston, 2007; Geens et al., 2007; Vandezande et al., 2008) and also facilitate clean water production.

\section{Membrane processes for the recovery of strategically important elements}

Pressure-driven membrane processes such as nanofiltration (NF) and reverse osmosis (RO) have been used for the separation of lithium from brine. Lithium was separated from diluted brine in the form of lithium chloride by using NF membranes (Wen et al., 2006). Separation of lithium from salt lake brines by the NF90 and a low-pressure RO membrane (LPRO) was investigated by Somrani et al. (2013). The NF90 membrane was found to be more efficient for lithium separation compared to LPRO. This is probably due to its high hydraulic permeability and separation efficiency of monovalent ions (e.g., lithium). In another study, effective retention (97\%) of divalent cations, namely $\mathrm{Mg}$ and $\mathrm{Ca}$, was achieved by $\mathrm{NF}$ membranes, while a moderate retention (70\%) was observed for monovalent cations (Na and Li) (Zhang et al., 2017), thus facilitating separation of lithium from the mixture. Separation of lithium and magnesium from brine using NF membranes has also been reported by (Sun et al., 2015) and (Pramanik et al., 2019). They found that magnesium and lithium separation was highly dependent on the $\mathrm{pH}$, operating pressure, and $\mathrm{Mg} / \mathrm{Li}$ ratio. The competitive coefficient was susceptible to the $\mathrm{Mg} / \mathrm{Li}$ ratio, when the $\mathrm{Mg} / \mathrm{Li}$ ratio was less than 20 (Sun et al., 2015). An NF membrane with polyamide functional layer and positive charge was fabricated for $\mathrm{Li}$ and $\mathrm{Mg}$ separation (Li, et al., 2015a,b). The results showed that the rejection 
difference between magnesium chloride and lithium chloride reached $47.5 \%$ and the $\mathrm{Mg} / \mathrm{Li}$ ratio decreased from 20 to 7.7. Li et al. (2017) synthesized a composite NF membrane with positively charged skin layer followed by modification with EDTA, which showed stable separation behaviour of lithium ions.

REEs such as cerium and neodymium can also be separated using NF membranes (Murthy and Choudhary, 2012). Rejection of neodymium ions from synthetic wastewater, as a function of applied pressure, feed concentration and $\mathrm{pH}$ was investigated using a NF membrane (Murthy and Choudhary, 2011). The rejection of neodymium ions increased with the increase in applied pressure and decreased with the increase in feed concentration. Rejection of neodymium using NF membrane was influenced by solution $\mathrm{pH}$ (Murthy and Choudhary, 2011). This was likely due to the charged nature of the membrane which changed with the variation in $\mathrm{pH}$ (Murthy and Choudhary, 2011).

Despite the potential of pressure-driven high retention membrane processes in the separation of strategically important elements, these processes have some limitations. These processes are energy-intensive and prone to severe membrane fouling, resulting in impaired membrane performance and shortened membrane lifetime. Hence, combination of emerging technologies such as membrane distillation (MD) and conventional processes such as electrodialysis (ED) can be potentially used to recover strategically important elements from brines. These processes can achieve a high concentration factor for strategically important elements by pre-concentrating brines. This is due to the mass transfer properties of the membranes. In addition, compared to RO/NF, these processes are expected to have lower energy consumption and lower fouling propensity due to low applied hydraulic pressure (Mazlan et al., 2016; McGovern, 2014). 
The application of MD process could concentrate strategically important elements to

400

401

402

403

404

405

406

407

408

409

410

411

412

413

414

415

416

417

418

419

420

421

facilitate their recovery and it can also produce clean water (Table 3). MD has the capability to concentrate salts up to the supersaturated state to allow crystallization (Ali et al., 2015). Studies reported that there is ample opportunity for the recovery of lithium from seawater brines using the MD-crystallization technique (Greenlee et al., 2009; Quist-Jensen, C. et al., 2016; Quist-Jensen, C.A. et al., 2016). Hollins (2013) evaluated the prospects for recovering minerals from desalination brines and focused on the extraction of Li from desalination brines as a benchmark. They noted that 23000 tonnes of Li could be recovered from brines by 2030 compared to the current global production of 37000 tonnes.

ED can efficiently achieve lithium recovery from brines. This process was demonstrated to recover lithium in the form of lithium bromide from a sodium-contaminated lithium bromide solution (Parsa et al., 2015) and lithium hydroxide from an aqueous solution (Bunani et al., 2017). After pre-concentrating and precipitating brine with sodium carbonate, $98 \%$ lithium carbonate could be obtained from simulated lake brines using ED with a bipolar membrane process (Jiang et al., 2014). The ED system can also be equipped with monovalent selective ion exchange membrane for the recovery of lithium from salt lake brines (Ji et al., 2017). In this way, the $\mathrm{Mg} / \mathrm{Li}$ ratio of simulated brine was reduced from 60 to 7 , which provided a suitable $\mathrm{Mg} / \mathrm{Li}$ condition for the extraction of lithium from the Li-enriched solution. However, the concentration of co-existing ions such as sodium, potassium and sulphate, differs considerably in different types of brine, which may influence the applicability of ED for lithium recovery (Nie et al., 2017a). In addition, the durability of the membranes is a challenge during long-term lithium recovery in this process (Jiang et al., 2014). 
423 Table 3: Examples of strategically important elements separation using membrane processes. 424

\begin{tabular}{|c|c|c|c|c|c|}
\hline Technology & Source & $\begin{array}{c}\text { Concentrate } \\
(\%)\end{array}$ & $\begin{array}{c}\text { Separated } \\
\text { elements }\end{array}$ & $\begin{array}{c}\text { Water } \\
\text { recovery (\%) }\end{array}$ & References \\
\hline \multirow[t]{8}{*}{ NF } & Salt lake & NA & Lithium & NA & Wen et al. (2006) \\
\hline & brine & & Lithium & & Somrani et al. (2013) \\
\hline & & & Lithium & & Sun et al. (2015) \\
\hline & Synthetic & NA & Lithium & NA & Zhang et al. (2017) \\
\hline & wastewater & & Cerium, & & Murthy and \\
\hline & & & Neodymium & & Choudhary (2012) \\
\hline & & & Neodymium & & Murthy and \\
\hline & & & & & Choudhary (2011) \\
\hline RO & $\begin{array}{l}\text { Salt lake } \\
\text { brine }\end{array}$ & NA & Lithium & NA & Somrani et al. (2013) \\
\hline \multirow[t]{3}{*}{$\mathrm{MD}$} & $\begin{array}{l}\text { Seawater } \\
\text { Brine }\end{array}$ & 500 & NA & 80 & Duong et al. (2015) \\
\hline & $\begin{array}{l}\text { Synthetic } \\
\text { brine }\end{array}$ & NA & Lithium & NA & $\begin{array}{l}\text { Quist-Jensen et al. } \\
\text { (2016b) }\end{array}$ \\
\hline & $\begin{array}{l}\text { Salt lake } \\
\text { brine }\end{array}$ & NA & Lithium & NA & Zhou (2017) \\
\hline \multirow[t]{7}{*}{ ED } & Salt lake & NA & Lithium & NA & Liu et al. (2015) \\
\hline & brino & & & & Jiang et al. (2014) \\
\hline & Geothermal & NA & Lithium & NA & Mroczek et al. \\
\hline & brine & & & & (2015) \\
\hline & Synthetic & NA & Lithium & NA & Nie et al. (2017b) \\
\hline & brine & & & & Bunani et al. (2017) \\
\hline & & & & & Parsa et al. (2015) \\
\hline
\end{tabular}

426

427

428

429

430

431

432

433

434 
435 A potential integrated process for the recovery of strategically important elements along with

436 clean water production is shown in Figure 5. In this process, membranes can be used to

437

438

439

440

441

442

443 concentrate the strategically important elements as well as produce clean water. Posttreatment with solvent extraction, ion exchange or precipitation process can be used to retrieve the target element selectively. For example, lithium could be effectively recovered from brines using integrated NF and MD processes. In a previous study, NF could only retain $26 \%$ of the lithium and $88 \%$ of magnesium from the seawater (Drioli et al., 2016). Thus, MD can be used to treat the NF permeate, and to concentrate lithium for recovery. NF could also be combined with the ED process by replacing the cation exchange membrane (Ge et al., 2016). The MD process can be also integrated with renewable energy sources. Low- grade or waste heat can be used to operate MD process. However, economic analysis is essential for the feasibility of the MD process since a considerable amount of energy is required to evaporate water to separate water from non-volatile contaminants (Kiss and Kattan Readi, 2018). Recently, Deshmukh et al. (2018) examined some critical factors that affect the energy efficiency of MD processes and also noted how future membrane design and process development could considerably boost MD efficiency. They found that the size of the system along with porosity and thickness of the membrane could significantly influence the performance of the process. The cost of the MD system operation may vary from 0.26 to 130 $\$ / \mathrm{m}^{3}$ based on the optimum flow conditions and MD configurations (Deshmukh et al. (2018). It was reported that by applying waste heat, the production cost of a $30,000 \mathrm{~m}^{3} / \mathrm{d}$ MD desalination plant could be reduced from 2.2 to $0.66 \$ / \mathrm{m}^{3}$ (Kesieme et al., 2013). However, currently limited number of studies is available on the investigation of such an integrated process for the recovery of these elements along with clean water production. 
459 The aforementioned membrane processes can concentrate strategically important elements in 460 the solution to enable their crystallisation. However, to date these lithium recovery processes 461 have been mainly tested at lab-scale. Therefore, the recovery of strategically important 462 elements along with clean water production from brines using these processes needs to be 463 further investigated. Particularly, the challenges associated with an integrated process, as 464 depicted in Figure 5, need to be addressed for the recovery of these elements and production 465 of clean water. Studies exploring application of MD on a large scale with a long-term 466 operational period reported several challenges of MD process (Van der Bruggen et al., 2008).

467 These include membrane fouling, scaling, and pore wetting which may restrict its commercial 468 application. When applied to brine treatment, inorganic fouling in the form of scaling is the 469 predominant form of fouling on the membrane surface (Van der Bruggen et al., 2008). 470 Therefore, it is necessary to fabricate novel membranes with characteristics of low resistance 471 to mass transfer, low thermal conductivity, high thermal stability and chemical resistance to 472 improve MD performance by minimising fouling and wetting phenomena, while enhancing 473 retention of target metal. In addition, there is a clear need to evaluate product purity, process 474 efficiency and life cycle costs. 


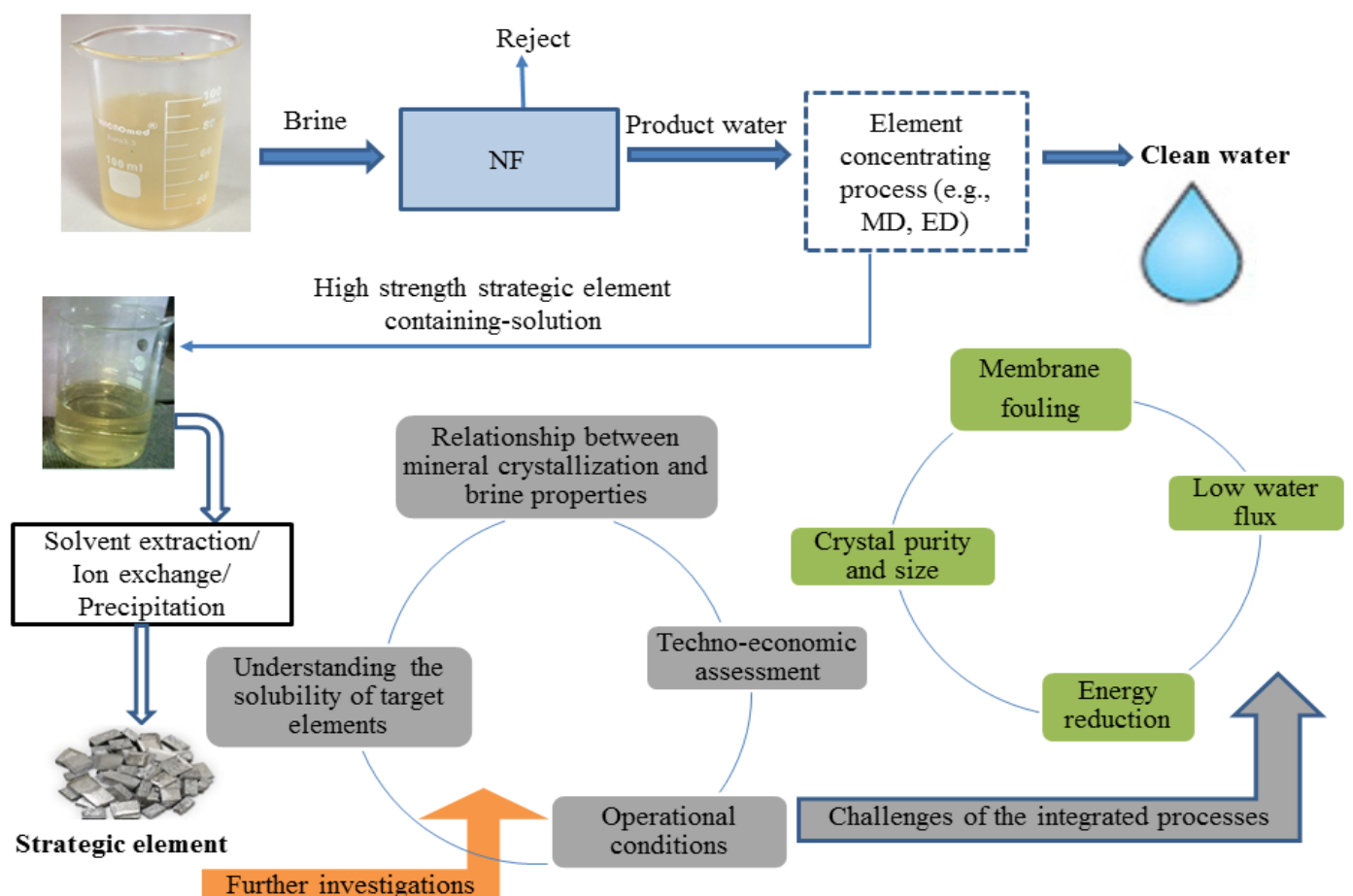

Figure 5. A roadmap of an integrated membrane and metal separation process for strategically important elements and clean water recovery

\section{Perspective}

The commercial viability of extracting metals is not only dependent on mineral concentration, technology implemented, recovery rates, commodity pricing and final product purity, but also market fluctuations for the minerals extracted (Shahmansouri et al., 2015; Teat, 2012). Wei (1982) followed by Brown (2016) showed the potential of mining minerals and metals from geothermal brines as a function of mineral concentration, value, demand, import dependency, strategic consideration, existing sources of supply, technology readiness level of recovery process, and resource uncertainty. They concluded that the recovery of REEs and platinum group elements (except lithium) from brine is still in its infancy stage. Both Stull (2016) and Addleman et al. (2016) show that although some of these strategic elements have a low supply risk, the recovery of REEs from geothermal brines is not economically feasible with the current market prices of fresh products. It is particularly 
difficult for the lower grade sources. However, a study by Grosjean et al. (2012) reported that

493

494

495

496

497

498

499

500

501

502

503

504

505

506

507

508

509

510

511

512

513

514

515

516 the lithium production costs from mining of spodumene is estimated to be $6-8 \$ / \mathrm{kg}$, which is not competitive with respect to the recovery cost from salt lake brines (2-3 $\$ / \mathrm{kg})$. The economic feasibility of mining from brine solution further improves when simultaneous water, energy and mineral extractions are considered as proposed in European funded project MEDINA and Global MVP project (Drioli et al., 2016; Drioli et al., 2011). Overall, there might be a trade-off between energy cost and production of strategically important elements along with clean water production at high water recoveries. However, a comprehensive techno-economic analysis between the operating cost of the technologies and price for the production of strategically important elements needs to be carried out.

\section{Conclusions}

Water and minerals such as metals are critical resources, and these resources are the building blocks of a sustainable society and the global economy. With population-increase and industrialization, the demand for these resources has increased. In this context, it is important to recover strategically important elements and clean water from low-grade sources such as brines as discussed in this article. This may open up an exciting gateway to reduce the overall cost and environmental burden of the ore-mining processes. The recovery of strategically important elements from brines compared to that from ores is still in the early stages of development. These elements often occur at low concentrations in brines, and, thus, are difficult to recover in presence of much higher concentrations of other minerals which can interfere with the separation and enrichment process. The main technologies used for producing metals from brines are based on precipitation, ion exchange and solvent extraction. A major challenge of these processes is separation selectivity. An integrated membrane-based process may be suitable for efficiently enriching strategically important elements for their 
subsequent recovery, and, thus, may have a substantial role in shaping the future of this industry. This may be an attractive pathway to bridge the gap between demand and supply of the strategically important elements.

\section{Acknowledgements}

A Vice-Chancellor’s Postdoctoral Research Fellowship to Dr Biplob Kumar Pramanik by the University of Wollongong, Australia is gratefully acknowledged.

\section{References}

Addleman, R.S., Chouyyok, W., Palo, D., Dunn, B.M., Brann, M., Billingsley, G., Johnson, D., Nell, K.M., 2016. In support of data uploaded for GTO program on: Evaluation of Advanced Sorbent Structures for Recovery of Rare Earths, Precious Metals and other Critical Materials from Geothermal Waters-Preliminary Results.

Al-Obaidani, S., Curcio, E., Macedonio, F., Di Profio, G., Al-Hinai, H., Drioli, E., 2008. Potential of membrane distillation in seawater desalination: thermal efficiency, sensitivity study and cost estimation. Journal of Membrane Science 323(1), 85-98.

Ali, A., Quist-Jensen, C.A., Macedonio, F., Drioli, E., 2015. Application of Membrane Crystallization for Minerals’ Recovery from Produced Water. Membranes 5(4), 772792.

Alonso, E., Sherman, A.M., Wallington, T.J., Everson, M.P., Field, F.R., Roth, R., Kirchain, R.E., 2012. Evaluating rare earth element availability: A case with revolutionary demand from clean technologies. Environmental Science \& Technology 46(6), 34063414.

An, J.W., Kang, D.J., Tran, K.T., Kim, M.J., Lim, T., Tran, T., 2012. Recovery of lithium from Uyuni salar brine. Hydrometallurgy 117, 64-70. 
542 Aral, H., Vo, B.S., McCallum, D., Barton, T., Norgate, T., 2009. High efficiency ion exchangewater recoveryfor mineral industry. CSIRO Minerals, 2009,DMR-3569

Bardi, U., 2010. Extracting minerals from seawater: an energy analysis. Sustainability 2(4), 980-992.

Barros, Ó., Costa, L., Costa, F., Lago, A., Rocha, V., Vipotnik, Z., Silva, B., Tavares, T., 2019. Recovery of Rare Earth Elements from Wastewater Towards a Circular Economy. Molecules 24(6), 1005.

Beolchini, F., Fonti, V., Ferella, F., Veglio, F., 2010. Metal recovery from spent refinery

Blokhin, A., Abovskiy, N., Murashkin, Y., Mikhaylenko, M., 2009. Sorption recovery of platinum and palladium from spent affinage solutions with their low contents, Proceeding of the 1st Int. Congress on Non-Ferrous Metals of Siberia, Krasnoyarsk, 587-592.

Brown, D.P., 2016. A Preliminary Feasibility Study of Geothermal and Mineral Extraction Applications of Hydrocarbon Wells.

Bukowsky, H., Uhlemann, E., Steinborn, D., 1991. The recovery of pure lithium chloride from "brines" containing higher contents of calcium chloride and magnesium chloride. Hydrometallurgy 27(3), 317-325.

Bunani, S., Arda, M., Kabay, N., Yoshizuka, K., Nishihama, S., 2017. Effect of process conditions on recovery of lithium and boron from water using bipolar membrane electrodialysis (BMED). Desalination 416, 10-15. 
Bush, J.A., Vanneste, J., Cath, T.Y., 2016. Membrane distillation for concentration of hypersaline brines from the Great Salt Lake: Effects of scaling and fouling on performance, efficiency, and salt rejection. Separation and Purification Technology 170, 78-91.

Callura, J.C., Perkins, K.M., Noack, C.W., Washburn, N.R., Dzombak, D.A., Karamalidis, A.K., 2018. Selective adsorption of rare earth elements onto functionalized silica particles. Green chemistry 20(7), 1515-1526.

Cardoso, C.E., Almeida, J.C., Lopes, C.B., Trindade, T., Vale, C., Pereira, E., 2019. Recovery of Rare Earth Elements by Carbon-Based Nanomaterials-A Review. Nanomaterials 9(6), 814.

Chen, P., Tang, S., Yue, H., Liu, C., Li, C., Liang, B., 2017. Lithium enrichment of high $\mathrm{Mg} / \mathrm{Li}$ ratio brine by precipitation of magnesium via combined CO2 mineralization and solvent extraction. Industrial and Engineering Chemistry Research 56(19), 56685678.

Chitrakar, R., Makita, Y., Ooi, K., Sonoda, A., 2014. Lithium recovery from salt lake brine by H2TiO3. Dalton Transactions 43(23), 8933-8939.

Chun-Te Lin, J., Livingston, A.G., 2007. Nanofiltration membrane cascade for continuous solvent exchange. Chemical Engineering Science 62(10), 2728-2736.

Constantinides, S., 2016. Permanent magnets in a changing world market, Arnold Magnetic Technologies.

CPM Group, 2017. The CPM platinum group metals yearbook 2017: New York, NY, CPM Group, 235 p. (Accessed February 26, 2018, at http://cpmgroup.com/ files/The\%20CPM\%20PGM\%20Yearbook\%202017\%20EBook.pdf.).

Crundwell, F.K., 2011. Extractive metallurgy of nickel, cobalt and platinum group metals. Elsevier. 
Deshmukh, A., Boo, C., Karanikola, V., Lin, S., Straub, A., P, Tong, T., Warsinger, D.M., Elimelech, M., 2018. Membrane distillation at the water-energy nexus: limits, opportunities, and challenges. Energy and Environmental Science 11(5), 1177-1196.

Drioli, E., Ali, A., Quist-Jensen, C.A., Macedonio, F., 2016. Water, energy and minerals from the sea, 2016 World Congress on Advances in Civil, Environmental and Materials Research. Republic of Korea.

Drioli, E., Criscuoli, A., Macedonio, F., 2011. Membrane based desalination: an integrated approach, IWA Publishing.

Dutta, T., Kim, K.-H., Uchimiya, M., Kwon, E.E., Jeon, B.-H., Deep, A., Yun, S.-T., 2016. Global demand for rare earth resources and strategies for green mining. Environmental Research 150, 182-190.

El-Awady, E.M., 2013. Recovery of rare earth elements as by-product from GATTAR (V) mineralization MSc Thesis, Benha University, Egypt.

Energy, M.P., 2019. http: //www.pureenergyminerals.com/.

Epstein, J., Feist, E., Zmora, J., Marcus, Y., 1981. Extraction of lithium from the dead sea. Hydrometallurgy 6(3-4), 269-275.

Fukuda, H., 2019. Lithium extraction from brine with ion exchange resin and ferric phosphate. University of British Columbia.

Gabra, G., Torma, A., 1978. Lithium chloride extraction by n-butanol. Hydrometallurgy 3(1), 23-33.

Ge, L., Wu, B., Li, Q., Wang, Y., Yu, D., Wu, L., Pan, J., Miao, J., Xu, T., 2016. Electrodialysis with nanofiltration membrane (EDNF) for high-efficiency cations fractionation. Journal of Membrane Science 498, 192-200. 
Geens, J., De Witte, B., Van der Bruggen, B., 2007. Removal of API's (active pharmaceutical ingredients) from organic solvents by nanofiltration. Separation Science and Technology 42(11), 2435-2449.

Gibert, O., Valderrama, C., Peterkova, M., Cortina, J.L., 2010. Evaluation of selective sorbents for the extraction of valuable metal ions (Cs, Rb, Li, U) from reverse osmosis rejected brine. Solvent Extraction and Ion Exchange 28(4), 543-562.

Graede, T., 2015. Metals used in high-tech products face future supply risks. . PNAS, https://phys.org/print346672145.html. .

Greenlee, L.F., Lawler, D.F., Freeman, B.D., Marrot, B., Moulin, P., 2009. Reverse osmosis desalination: water sources, technology, and today's challenges. Water Research 43(9), 2317-2348.

Grosjean, C., Miranda, P.H., Perrin, M., Poggi, P., 2012. Assessment of world lithium resources and consequences of their geographic distribution on the expected development of the electric vehicle industry. Renewable and Sustainable Energy Reviews 16(3), 1735-1744.

Harland, C.E., 1994. Ion exchange: theory and practice. Royal Society of Chemistry. ISBN 978-0-85186-484-6.

Hoenderdaal, S., Espinoza, L.T., Marscheider-Weidemann, F., Graus, W., 2013. Can a dysprosium shortage threaten green energy technologies? Energy 49, 344-355.

Hollins, O., 2013. Seawater mining: Mining desalination brine residues.

Hu, Y., Florek, J., Larivière, D., Fontaine, F.G., Kleitz, F., 2018. Recent advances in the separation of rare earth elements using mesoporous hybrid materials. The Chemical Record 18(7-8), 1261-1276.

Hubicki, Z., Wawrzkiewicz, M., Wołowicz, A., 2008. Application of ion exchange methods in recovery of Pd (II) ions-a review. Chem. Anal.(Warsaw) 53, 759-784. 
Hui, Z., 2000. Property of H2TiO3 type ion-exchangers and extraction of lithium from brine of natural gas wells. Chinese Journal of Applied Chemistry 17(3), 307-309.

Hurst, C., 2010. China's rare earth elements industry: What can the west learn? Institute for the Analysis of Global Security Washington DC.

IDC, 2013. Opportunities for downstream value addition in the platinum group metals value chain: fuel cells. South Africa Department of Research and Information.

Izatt, R.M., Izatt, S.R., Bruening, R.L., Izatt, N.E., Moyer, B.A., 2014. Challenges to achievement of metal sustainability in our high-tech society. Chemical Society Reviews 43(8), 2451-2475.

Izatt, R.M., Izatt, S.R., Izatt, N.E., Krakowiak, K.E., Bruening, R.L., Navarro, L., 2015. Industrial applications of molecular recognition technology to separations of platinum group metals and selective removal of metal impurities from process streams. Green Chemistry 17(4), 2236-2245.

Izatt, S.R., McKenzie, J.S., Izatt, N.E., Bruening, R.L., Krakowiak, K.E., and , R.M., I., 2016. Molecular recognition technology: a green chemistry process for separation of individual rare earth metals. White Paper on Separation of Rare Earth Elements, February, 1-13.

Jha, M.K., Kumari, A., Panda, R., Kumar, J.R., Yoo, K., Lee, J.Y., 2016. Review on hydrometallurgical recovery of rare earth metals. Hydrometallurgy 165, 2-26.

Ji, Z.-Y., Chen, Q.-B., Yuan, J.-S., Liu, J., Zhao, Y.-Y., Feng, W.-X., 2017. Preliminary study on recovering lithium from high $\mathrm{Mg} 2+/ \mathrm{Li}+$ ratio brines by electrodialysis. Separation and Purification Technology 172, 168-177.

Jiang, C., Wang, Y., Wang, Q., Feng, H., Xu, T., 2014. Production of lithium hydroxide from lake brines through electro-electrodialysis with bipolar membranes (EEDBM). Industrial and Engineering Chemistry Research 53(14), 6103-6112. 
Johnson, M., 2001. Platinum 2001: Interim Review. Johnson Matthey Public Limited Company, London, UK (32 pp.).

Johnson, M., 2014. PGM Market Report November 2014. Forecast of Platinum. Supply \& Demand in 2014. Johnson Matthey Public Limited Company, London, UK (32 pp.).

Jollie, D., 2017. Overview of PGM Markets. Available online: http://www.angloamerican.com/ /media/Files/A/Anglo-American-PLCV2/documents/platinum-marketing-david-jollie-241116.pdf (accessed on 10 May 2017).

Katsutoshi, I., Durga, P., Kanjana, K., 2008. Adsorption of precious metals on some lignophenol compounds. Vladivostok, Russia: Institute of Chemistry, Far East Branch of Russian Academy of Sciences (FEB RAS), 220-226.

Kentish, S., Stevens, G., 2001. Innovations in separations technology for the recycling and reuse of liquid waste streams. Chemical Engineering Journal 84(2), 149-159.

Kesieme, U.K., Milne, N., Aral, H., Cheng, C.Y., Duke, M., 2013. Economic analysis of desalination technologies in the context of carbon pricing, and opportunities for membrane distillation. Desalination 323, 66-74.

Khawassek, Y., Eliwa, A., Gawad, E., Abdo, S., 2015. Recovery of rare earth elements from El-Sela effluent solutions. Journal of Radiation Research and Applied Sciences 8(4), 583-589.

Kim, D., Powell, L.E., Delmau, L.H., Peterson, E.S., Herchenroeder, J., Bhave, R.R., 2015. Selective extraction of rare earth elements from permanent magnet scraps with membrane solvent extraction. Environmental Science and Technology 49(16), 94529459.

Kiss, A.A., Kattan Readi, O.M., 2018. An industrial perspective on membrane distillation processes. Journal of Chemical Technology and Biotechnology 93(8), 2047-2055. 
690

691

692

693

694

695

696

697

698

699

700

701

702

703

704

705

706

707

708

709

710

711

712

Kogel, J.E., 2006. Industrial minerals \& rocks: commodities, markets, and uses. SME.

Koltun, P., Tharumarajah, A., 2014. Life cycle impact of rare earth elements. ISRn Metallurgy 2014.

Kondo, Y., Kubota, M., 1992. Precipitation behavior of platinum group metals from simulated high level liquid waste in sequential denitration process. Journal of Nuclear Science and Technology 29(2), 140-148.

Kononova, O., Leyman, T., Melnikov, A., Kashirin, D., Tselukovskaya, M., 2010. Ion exchange recovery of platinum from chloride solutions. Hydrometallurgy 100(3-4), 161-167.

Kononova, O., Melnikov, A., Borisova, T., Krylov, A., 2011. Simultaneous ion exchange recovery of platinum and rhodium from chloride solutions. Hydrometallurgy 105(34), 341-349.

Kotsupalo, N., Ryabtsev, A., Poroshina, I., Kurakov, A., Mamylova, E., Menzheres, L., Korchagin, M., 2013. Effect of structure on the sorption properties of chlorinecontaining form of double aluminum lithium hydroxide. Russian Journal of Applied Chemistry 86(4), 482-487.

Krishnamurthy, N., Gupta, C.K., 2004. Extractive metallurgy of rare earths. CRC press.

Lacal-Arántegui, R., Serrano-González, J.,, 2015. 2014 JRC wind status report; Joint Research Centre (JRC). Publications Office of the European Union. EUR 27254 EN. http://dx.doi.org/10.2790/676580.

Larsson, K., Ekberg, C., Ødegaard-Jensen, A., 2012. Using Cyanex 923 for selective extraction in a high concentration chloride medium on nickel metal hydride battery waste. Hydrometallurgy 129, 35-42. 
Lee, J., Yu, S.-H., Kim, C., Sung, Y.-E., Yoon, J., 2013. Highly selective lithium recovery from brine using a $\lambda-\mathrm{MnO} 2-\mathrm{Ag}$ battery. Physical Chemistry Chemical Physics 15(20), 7690-7695.

Lee, S.H., Jung, C.H., Shon, J.S., Chung, H., 2000. Separation of palladium from a simulated radioactive liquid waste by precipitation using ascorbic acid. Separation Science and Technology 35(3), 411-420.

Li, W., Shi, C., Zhou, A., He, X., Sun, Y., Zhang, J., 2017. A positively charged composite nanofiltration membrane modified by EDTA for $\mathrm{LiCl} / \mathrm{MgCl}$. Separation and Purification Technology 186, 233-242.

Li, X., Zhang, C., Zhang, S., Li, J., He, B., Cui, Z., 2015a. Preparation and characterization of positively charged polyamide composite nanofiltration hollow fiber membrane for lithium and magnesium separation. Desalination 369, 26-36.

Li, Y., Zhao, Z., Liu, X., Chen, X., Zhong, M., 2015b. Extraction of lithium from salt lake brine by aluminum-based alloys. Transactions of Nonferrous Metals Society of China 25(10), 3484-3489.

Liu, Zhang, H., Zhang, Y., Cao, D., Zhao, X., 2015. Lithium extraction from seawater by manganese oxide ion sieve $\mathrm{MnO} 2 \cdot 0.5 \mathrm{H} 2 \mathrm{O}$. Colloids Surfaces A: Physicochemical Engineering Aspects 468, 280-284.

Liu, X., Zhong, M., Chen, X., Zhao, Z., 2018. Separating lithium and magnesium in brine by aluminum-based materials. Hydrometallurgy 176, 73-77.

Loferski, P.J., 2011. 2010 minerals yearbook: Platinum-group metals. US Department of the Interior, US Geological Survey.

MacLean, H., Duchin, F., Hagelücken, C., Halada, K., Kesler, S., Moriguchi, Y., Mueller, D., Norgate, T., Reuter, M., Van der Voet, E., 2009. Stocks, flows, and prospects of mineral resources. Linkages of sustainability. 
Makanyire, T., Sanchez-Segado, S., Jha, A., 2016. Separation and recovery of critical metal ions using ionic liquids. Advances in Manufacturing 4(1), 33-46.

Marchetti, P., Jimenez Solomon, M.F., Szekely, G., Livingston, A.G., 2014. Molecular separation with organic solvent nanofiltration: a critical review. Chemical reviews 114(21), 10735-10806.

Martin, G., Rentsch, L., Höck, M., Bertau, M., 2017. Lithium market research-global supply, future demand and price development. Energy Storage Materials 6, 171-179.

Mazlan, N.M., Peshev, D., Livingston, A.G., 2016. Energy consumption for desalination-A comparison of forward osmosis with reverse osmosis, and the potential for perfect membranes. Desalination 377, 138-151.

McGovern, R.K., 2014. On the potential of forward osmosis to energetically outperform reverse osmosis desalination. Journal of Membrane Science 469, 245-250.

Mel’nikov, A., Kononova, O., Ozerova, T., Luk’yanenko, A., 2012. Sorption recovery of platinum (II, IV) from chloride and sulfate-chloride solutions. Russian Journal of Applied Chemistry 85(10), 1560-1566.

Moss, R., Tzimas, E., Kara, H., Willis, P., Kooroshy, J., 2011. Critical metals in strategic energy technologies. JRC-scientific and strategic reports, European Commission Joint Research Centre Institute for Energy and Transport.

Moss, R., Tzimas, E., Willis, P., Arendorf, J., Thompson, P., Chapman, A., Morley, N., Sims, E., Bryson, R., Peason, J., 2013. Critical metals in the path towards the decarbonisation of the EU energy sector. Assessing rare metals as supply-chain bottlenecks in low-carbon energy technologies. JRC Report EUR 25994.

Mroczek, E., Dedual, G., Graham, D., Bacon, L., 2015. Lithium extraction from Wairakei geothermal fluid using electrodialysis, Proceedings World Geothermal Congress. p. 2015. 
Murthy, Z., Choudhary, A., 2011. Application of nanofiltration to treat rare earth element (neodymium) containing water. Journal of rare earths 29(10), 974-978.

Murthy, Z.V.P., Choudhary, A., 2012. Separation and estimation of nanofiltration membrane transport parameters for cerium and neodymium. Rare Metals 31(5), 500.

Nie, X.-Y., Sun, S.-Y., Song, X., Yu, J.-G., 2017a. Further investigation into lithium recovery from salt lake brines with different feed characteristics by electrodialysis. Journal of Membrane Science 530, 185-191.

Nie, X.-Y., Sun, S.-Y., Sun, Z., Song, X., Yu, J.-G., 2017b. Ion-fractionation of lithium ions from magnesium ions by electrodialysis using monovalent selective ion-exchange membranes. Desalination 403, 128-135.

Nikoloski, A.N., Ang, K.-L., Li, D., 2015. Recovery of platinum, palladium and rhodium from acidic chloride leach solution using ion exchange resins. Hydrometallurgy 152, 20-32.

Nishihama, S., Hirai, T., Komasawa, I., 2003. Advanced liquid-liquid extraction systems for the separation of rare earth ions by combination of conversion of the metal species with chemical reaction. Journal of Solid State Chemistry 171(1), 101-108.

Nishihama, S., Onishi, K., Yoshizuka, K., 2011. Selective recovery process of lithium from seawater using integrated ion exchange methods. Solvent Extraction and Ion Exchange 29(3), 421-431.

Norgate, T., Haque, N., 2010. Energy and greenhouse gas impacts of mining and mineral processing operations. Journal of Cleaner Production 18(3), 266-274.

Ogawa, Y., Koibuchi, H., Suto, K., Inoue, C., 2014. Effects of the chemical compositions of Salars de Uyuni and Atacama brines on lithium concentration during evaporation. Resource Geology 64(2), 91-101. 
Paranthaman, M.P., Li, L., Luo, J., Hoke, T., Ucar, H., Moyer, B.A., Harrison, S., 2017. Recovery of lithium from geothermal brine with lithium-aluminum layered double hydroxide chloride sorbents. Environmental Science and Technology 51(22), 1348113486.

Park, H., Singhal, N., Jho, E.H., 2015. Lithium sorption properties of HMnO in seawater and wastewater. Water Research 87, 320-327.

Parsa, N., Moheb, A., Mehrabani-Zeinabad, A., Masigol, M.A., 2015. Recovery of lithium ions from sodium-contaminated lithium bromide solution by using electrodialysis process. Chemical Engineering Research and Design 98, 81-88.

Pathak, A.K., Khan, M., Gschneidner Jr, K.A., McCallum, R.W., Zhou, L., Sun, K., Dennis, K.W., Zhou, C., Pinkerton, F.E., Kramer, M.J., 2015. Cerium: an unlikely replacement of dysprosium in high performance $\mathrm{Nd}-\mathrm{Fe}-\mathrm{B}$ permanent magnets. Advanced Materials 27(16), 2663-2667.

Pavel, C.C., Lacal-Arántegui, R., Marmier, A., Schüler, D., Tzimas, E., Buchert, M., Jenseit, W., Blagoeva, D., 2017. Substitution strategies for reducing the use of rare earths in wind turbines. Resources Policy 52, 349-357.

Pavel, C.C., Marmier, A., Tzimas, E., Schleicher, T., Schüler, D., Buchert, M., Blagoeva, D., 2016. Critical raw materials in lighting applications: Substitution opportunities and implication on their demand. Physica Status Solidi 213(11), 2937-2946.

Pelly, I., 1978. Recovery of lithium from Dead Sea brines. Journal of Applied Chemistry and Biotechnology 28(7), 469-474.

Peng, L., Liu, G.-F., Chen, D.-L., Cheng, S.-Y., Ning, T., 2009. Adsorption properties of Ag (I), Au (III), Pd (II) and Pt (IV) ions on commercial 717 anion-exchange resin. Transactions of Nonferrous Metals Society of China 19(6), 1509-1513. 
Perez, J.P.H., Folens, K., Leus, K., Vanhaecke, F., Van Der Voort, P., Du Laing, G., 2019. Progress in hydrometallurgical technologies to recover critical raw materials and precious metals from low-concentrated streams. Resources, Conservation and Recycling 142, 177-188.

Phetla, T., Muzenda, E., Belaid, M., 2010. A Study of the Variables in the Optimisation of a Platinum Precipitation Process. World Academy of Science, Engineering and Technology 45, 248-254.

Pramanik, B.K., Asif, M.B., Kentish, S., Nghiem, L.D., Hai, F.I., 2019. Lithium enrichment from a simulated salt lake brine using an integrated nanofiltration-membrane distillation process. Journal of Environmental Chemical Engineering, 103395.

Quist-Jensen, C., Macedonio, F., Drioli, E., 2016. Membrane crystallization for salts recovery from brine-an experimental and theoretical analysis. Desalination and Water Treatment 57(16), 7593-7603.

Quist-Jensen, C.A., Macedonio, F., Drioli, E., 2016. Integrated Membrane Desalination Systems with Membrane Crystallization Units for Resource Recovery: A New Approach for Mining from the Sea. Crystals 6(4), 36.

Rabie, K., 2007. A group separation and purification of Sm, Eu and Gd from Egyptian beach monazite mineral using solvent extraction. Hydrometallurgy 85(2), 81-86.

Reddy, B.R., Raju, B., Lee, J.Y., Park, H.K., 2010. Process for the separation and recovery of palladium and platinum from spent automobile catalyst leach liquor using LIX 84I and Alamine 336. Journal of Hazardous Materials 180(1-3), 253-258.

Roskill, 2015. Rare earths: market outlook to 2020, 15th Edition ed, Roskill, London.

Safarzadeh, M.S., Horton, M., Van Rythoven, A.D., 2018. Review of recovery of platinum group metals from copper leach residues and other resources. Mineral Processing and Extractive Metallurgy Review 39(1), 1-17. 
Saito, T., Sato, H., Motegi, T., 2006. Recovery of rare earths from sludges containing rareearth elements. Journal of Alloys and Compounds 425(1), 145-147.

Shahmansouri, A., Min, J., Jin, L., Bellona, C., 2015. Feasibility of extracting valuable minerals from desalination concentrate: a comprehensive literature review. Journal of Cleaner Production 100, 4-16.

Shi, C., Jing, Y., Jia, Y., 2016. Solvent extraction of lithium ions by tri-n-butyl phosphate using a room temperature ionic liquid. Journal of Molecular Liquids 215, 640-646.

Shi, D., Li, J., Zhang, B., Nie, F., Zeng, Z., Li, L., 2013. Process study on N523-TBPsulfonated kerosene extraction system for extraction of lithium from brine saturated by magnesium chloride. Journal of Salt Lake Research 21(2), 52-57.

Shimojo, K., Kurahashi, K., Naganawa, H., 2008. Extraction behavior of lanthanides using a diglycolamide derivative TODGA in ionic liquids. Dalton Transactions(37), 50835088.

Singh, D., Kotekar, M., Singh, H., 2008. Development of a solvent extraction process for production of nuclear grade dysprosium oxide from a crude concentrate. Desalination 232(1), 49-58.

Sitando, O., Crouse, P.L., 2012. Processing of a Zimbabwean petalite to obtain lithium carbonate. International Journal of Mineral Processing 102, 45-50.

Skirrow, R.G., Huston, D.L., Mernagh, T.P., Thorne, J.P., Dulfer, H., Senior, A., 2013. Critical commodities for a high-tech world: Australia's potential to supply global demand. Geoscience Australia, Canberra.

Somrani, A., Hamzaoui, A., Pontie, M., 2013. Study on lithium separation from salt lake brines by nanofiltration (NF) and low pressure reverse osmosis (LPRO). Desalination 317, 184-192. 
Song, J.F., Nghiem, L.D., Li, X.-M., He, T., 2017. Lithium extraction from Chinese salt-lake brines: opportunities, challenges, and future outlook. Environmental Science: Water Research and Technology.

Stull, D.P., 2016. Environmentally friendly economical sequestration of rare earth metals from geothermal waters. Tusaar Corp., Lafayette, CO (United States).

Sun, P., Lee, J., Lee, M., 2012. Separation of platinum (IV) and rhodium (III) from acidic chloride solution by ion exchange with anion resins. Hydrometallurgy 113, 200-204.

Sun, S.-Y., Cai, L.-J., Nie, X.-Y., Song, X., Yu, J.-G., 2015. Separation of magnesium and lithium from brine using a Desal nanofiltration membrane. Journal of Water Process Engineering 7, 210-217.

Székely, G., Bandarra, J., Heggie, W., Sellergren, B., Ferreira, F.C., 2012. A hybrid approach to reach stringent low genotoxic impurity contents in active pharmaceutical ingredients: Combining molecularly imprinted polymers and organic solvent nanofiltration for removal of 1, 3-diisopropylurea. Separation and Purification Technology 86, 79-87.

Tanskanen, P., 2013. Management and recycling of electronic waste. Acta Materialia 61(3), 1001-1011.

Teat, S., 2012. Industrial Symbiosis Kawerau - Minerals Background Study, 1-6.

Teske, S., Florin, N., Dominish, E., Giurco, D., 2016. Renewable energy and deep sea mining: supply, demand and scenarios. Report prepared by ISF for JM Kaplan Fund, Oceans 5.

Tharumarajah, R., Koltun, P., 2011. Cradle to gate assessment of environmental impact of rare earth metals, Proceedings of the 7th Australian Conference on Life Cycle Assessment, Melbourne, Australia. pp. 9-10. 
884

885

886

887

888

889

890

891

892

893

894

895

896

897

898

899

900

901

902

903

904

905

906

907

Thormann, L., Buchspies, B., Mbohwa, C., Kaltschmitt, M., 2017. PGE production in Southern Africa, part I: Production and market trends. Minerals 7(11), 224.

Timms, B.V., 2005. Salt lakes in Australia: present problems and prognosis for the future. Hydrobiologia 552(1), 1-15.

USGS, 2016. Mineral Commodity Summaries 2016, in: Survey, U.S.G. (Ed.). Government Printing Office.

USGS, 2019. Mineral Commodity Summaries , United State Geological Survey, Government Printing Office.

Van der Bruggen, B., Mänttäri, M., Nyström, M., 2008. Drawbacks of applying nanofiltration and how to avoid them: a review. Separation and Purification Technology 63(2), 251263.

Vandezande, P., Gevers, L.E., Vankelecom, I.F., 2008. Solvent resistant nanofiltration: separating on a molecular level. Chemical Society Reviews 37(2), 365-405.

Virolainen, S., Fini, M.F., Miettinen, V., Laitinen, A., Haapalainen, M., Sainio, T., 2016. Removal of calcium and magnesium from lithium brine concentrate via continuous counter-current solvent extraction. Hydrometallurgy 162, 9-15.

Wang, X.-H., Zheng, S.-L., Xu, H.-B., Zhang, Y., 2010. Dissolution behaviors of Ta2O5, Nb2O5 and their mixture in $\mathrm{KOH}$ and $\mathrm{H} 2 \mathrm{O}$ system. Transactions of Nonferrous Metals Society of China 20(10), 2006-2011.

Wang, Y., Liao, W., Li, D., 2011. A solvent extraction process with mixture of CA12 and Cyanex272 for the preparation of high purity yttrium oxide from rare earth ores. Separation and Purification Technology 82, 197-201.

Wei, M.S.J.I.T.G.R.S., 1982. Potential for recovery of by-products from spent geothermal fluids. 6 . 
Wen, X., Ma, P., Zhu, C., He, Q., Deng, X., 2006. Preliminary study on recovering lithium chloride from lithium-containing waters by nanofiltration. Separation and Purification Technology 49(3), 230-236.

Wittstock, R., Pehlken, A., Wark, M., 2016. Challenges in Automotive Fuel Cells Recycling. Recycling 1(3), 343-364.

Xiang, W., Liang, S., Zhou, Z., Qin, W., Fei, W., 2016. Extraction of lithium from salt lake brine containing borate anion and high concentration of magnesium. Hydrometallurgy 166, 9-15.

Xing, L., Song, J., Li, Z., Liu, J., Huang, T., Dou, P., Chen, Y., Li, X.-M., He, T., 2016. Solvent stable nanoporous poly (ethylene-co-vinyl alcohol) barrier membranes for liquid-liquid extraction of lithium from a salt lake brine. Journal of Membrane Science 520, 596-606.

Xiong, C., Xinyi, C., Caiping, Y., 2011. Enhanced adsorption behavior of Nd (III) onto D113-III resin from aqueous solution. Journal of Rare Earths 29(10), 979-985.

Yahorava, V., Kotze, M., 2014. Ion exchange technology for the efficient recovery of precious metals from waste and low-grade streams. Journal of the Southern African Institute of Mining and Metallurgy 114(2), 173-181.

Yang, F., Chen, S., Shi, C., Xue, F., Zhang, X., Ju, S., Xing, W., 2018. A facile synthesis of hexagonal spinel $\lambda$-MnO2 ion-sieves for highly selective $\mathrm{Li}+$ adsorption. Processes 6(5), 59.

Yang, X.J., Lin, A., Li, X.-L., Wu, Y., Zhou, W., Chen, Z., 2013. China's ion-adsorption rare earth resources, mining consequences and preservation. Environmental Development 8, 131-136.

Yi, D., Xiao, L., Wang, B., Tian, Z., Zhu, B., Yu, H., 2018. Method for quickly extracting lithium carbonate from saline lake water. Google Patents. 
Zandevakili, S., Ranjbar, M., Ehteshamzadeh, M., 2014. Recovery of lithium from Urmia Lake by a nanostructure MnO2 ion sieve. Hydrometallurgy 149, 148-152.

Zhang, H.-Z., Xu, Z.-L., Ding, H., Tang, Y.-J., 2017. Positively charged capillary nanofiltration membrane with high rejection for $\mathrm{Mg} 2+$ and $\mathrm{Ca} 2+$ and good separation for Mg2+ and Li+. Desalination 420, 158-166.

Zhang, J., Dow, N., Duke, M., Ostarcevic, E., Gray, S., 2010. Identification of material and physical features of membrane distillation membranes for high performance desalination. Journal of Membrane Science 349(1-2), 295-303.

Zhang, J., Everson, M.P., Wallington, T.J., Field III, F.R., Roth, R., Kirchain, R.E., 2016. Assessing economic modulation of future critical materials use: the case of automotive-related platinum group metals. Environmental Science and Technology 50(14), 7687-7695.

Zhao, Z., Si, X., Liu, X., He, L., Liang, X., 2013. Li extraction from high Mg/Li ratio brine with LiFePO 4/FePO 4 as electrode materials. Hydrometallurgy 133, 75-83. 7 

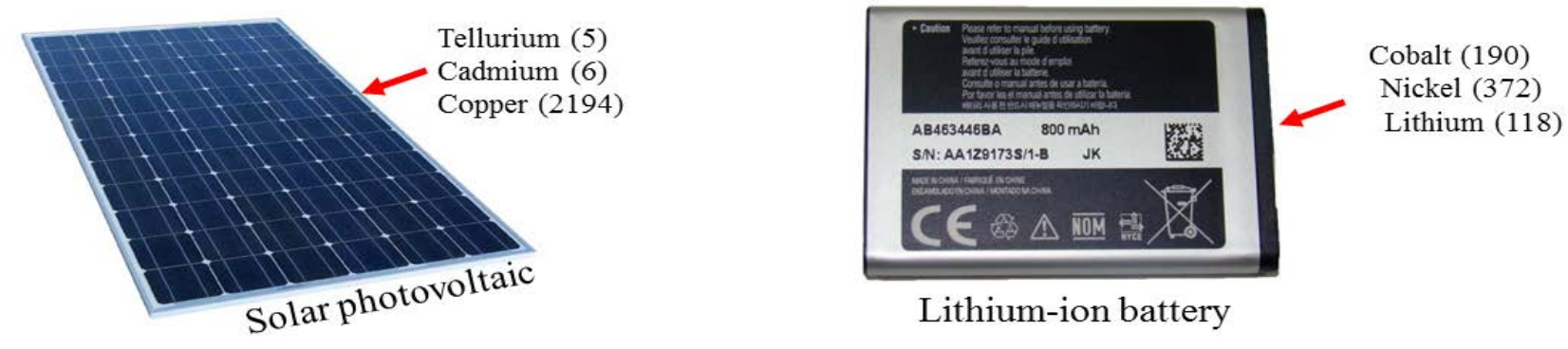

Lithium-ion battery

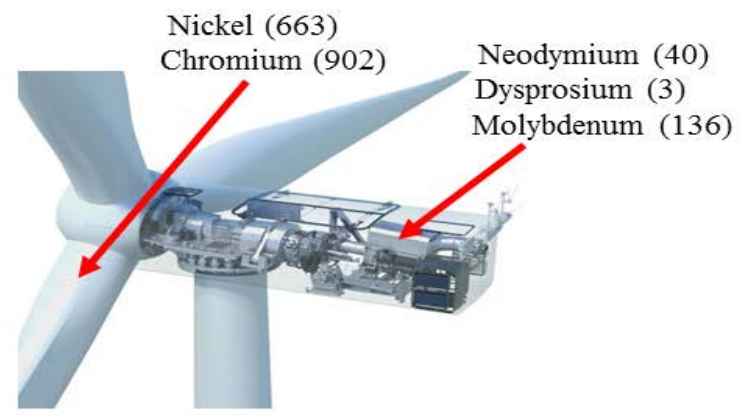

Wind turbine

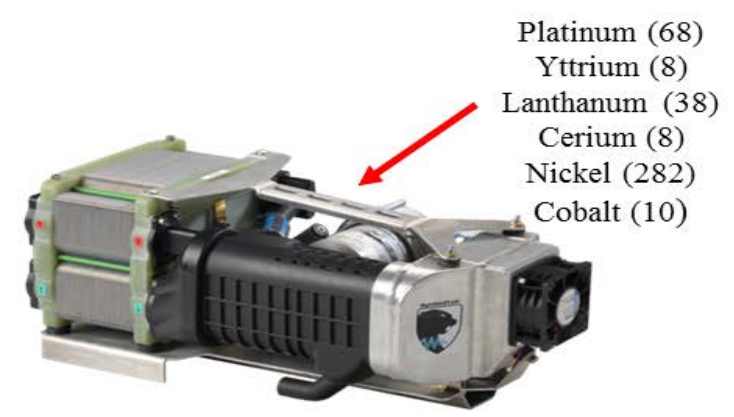

Fuel cell

Figure 1: Examples of strategically important element demand (kg/MW) in the renewable energy industry (Moss et al., 2011; Moss et al., 2013; Teske et al., 2016). 


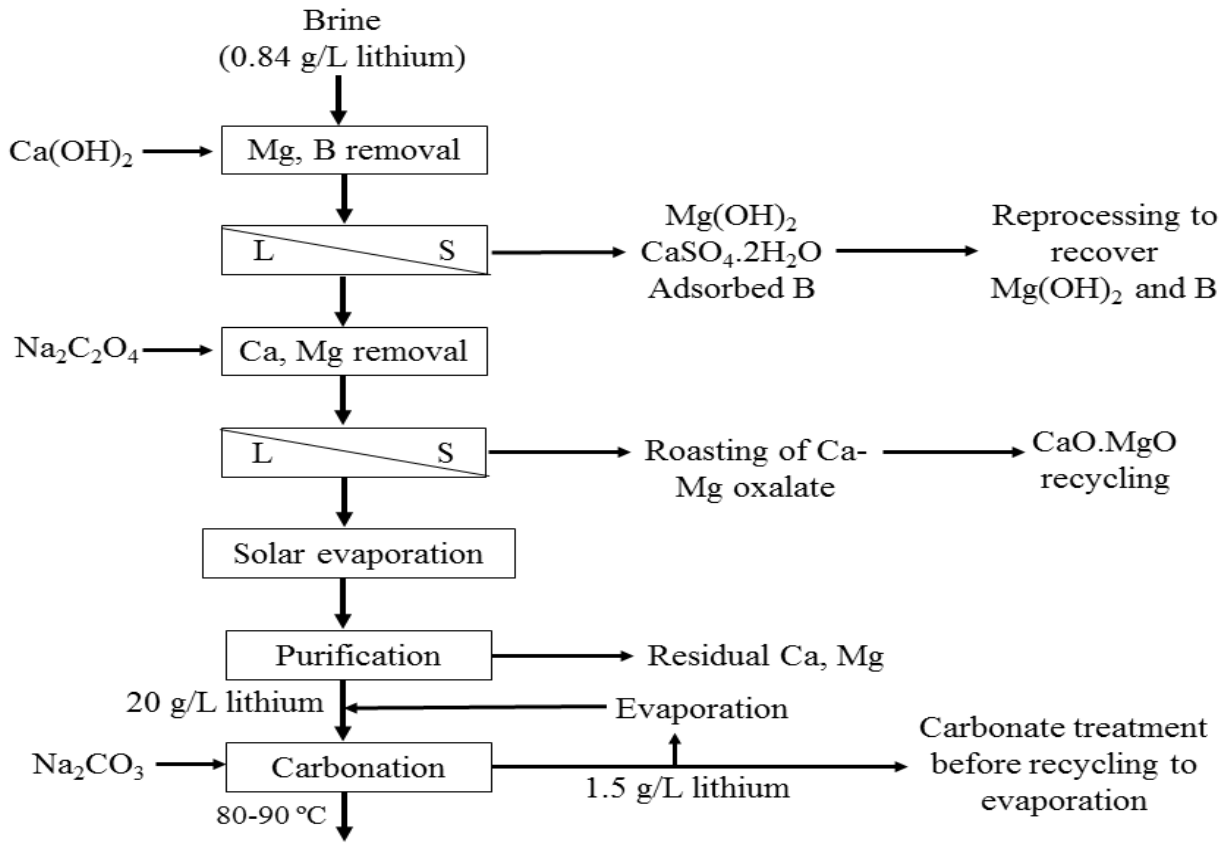

Lithium carbonate (99.6\%)

Figure 2: Flowsheet for the recovery of lithium as carbonate from Uyuni Salar brine, Bolivia

(An et al., 2012) 
Platinum-group metal concentrates

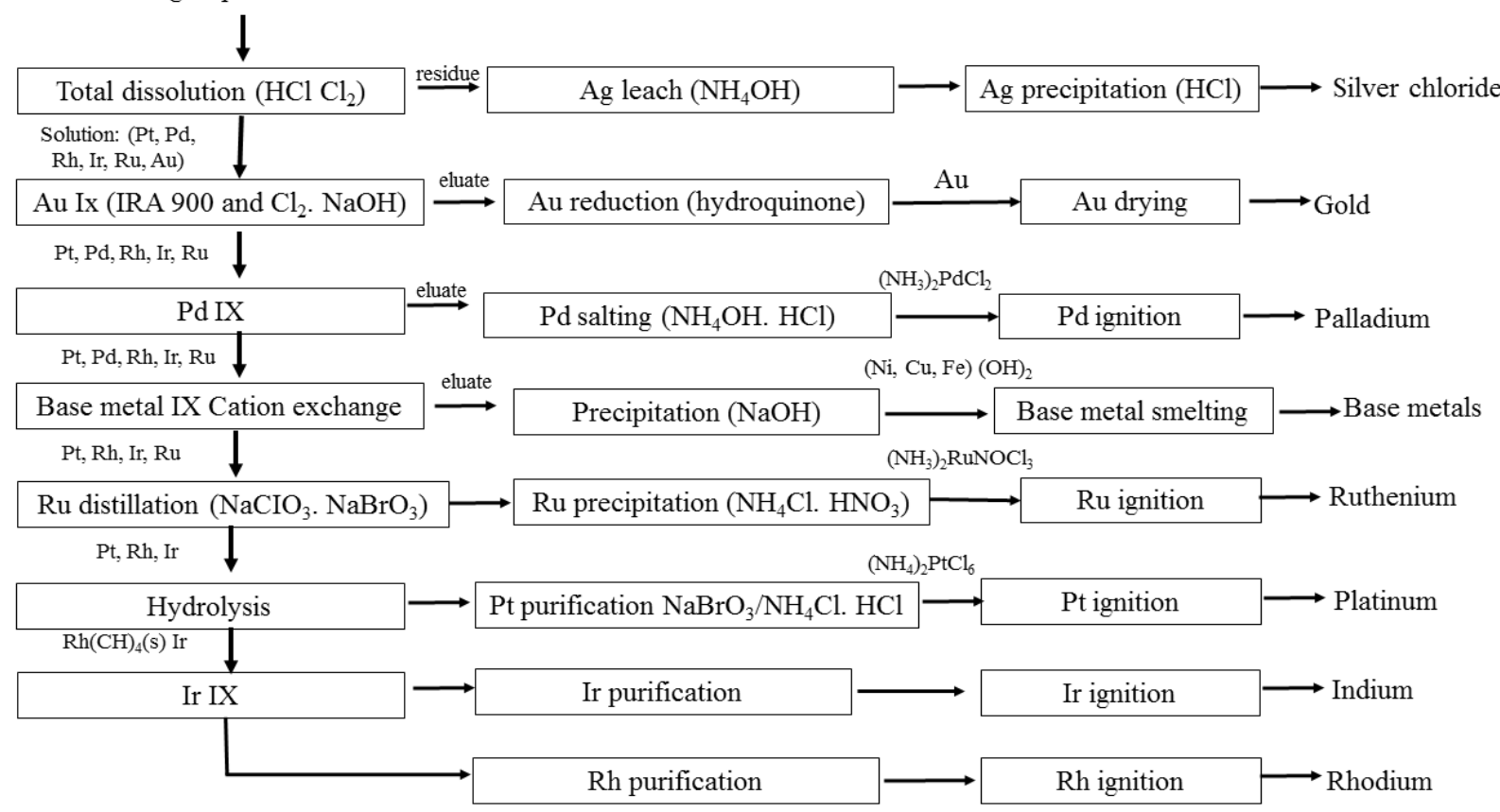

Figure 3: Platinum-group metals and other precious metal recovery using ion exchange process at Springs, South Africa (Crundwell, 2011). 
Rare earth nitrate feed

(lanthanum, praseodymium, neodymium and samarium)

Pure TBP $\longrightarrow$ Solvent extraction $\longrightarrow$ Raffinate: lanthanum, praseodymium

Neodymium and samarium

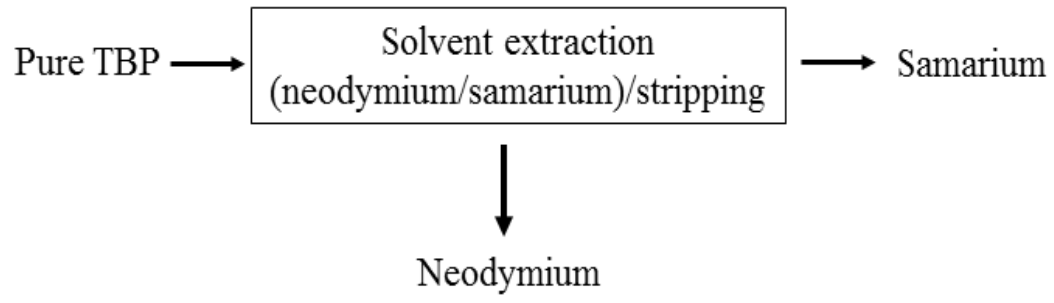

Figure 4: Flowsheet of rare earth separations by solvent extraction at Alwaye Plant of Indian Rare Earths Ltd, India (Krishnamurthy \& Gupta, 2004). 




Figure 5. A roadmap of an integrated membrane and metal separation process for strategically important elements and clean water recovery 
Table 1: The production, resources and reserve status of some prospective elements in Australia and their application for different purposes

(Hoenderdaal et al., 2013; Skirrow et al., 2013; USGS, 2016)

\begin{tabular}{|c|c|c|c|c|c|c|c|}
\hline \multirow[t]{2}{*}{ Metals } & \multicolumn{2}{|c|}{ Production } & \multicolumn{2}{|c|}{ Resource } & \multicolumn{2}{|c|}{ Reserve } & \multirow[t]{2}{*}{ Applications } \\
\hline & $\begin{array}{c}\text { Mass } \\
(\mathbf{k t})\end{array}$ & $\begin{array}{c}\text { Global share } \\
\text { (\%) }\end{array}$ & $\begin{array}{c}\text { Mass } \\
(\mathbf{k t})\end{array}$ & $\begin{array}{c}\text { Global share } \\
\text { (\%) }\end{array}$ & $\begin{array}{c}\text { Mass } \\
(\mathbf{k t})\end{array}$ & $\begin{array}{c}\text { Global share } \\
\text { (\%) }\end{array}$ & \\
\hline Cerium & 7.6 & 8 & 1481 & 3 & NA & 2.8 & $\begin{array}{l}\text { Catalytic converters in cars, hybrid vehicles, television } \\
\text { faceplates, silicon microprocessors. }\end{array}$ \\
\hline Lanthanum & 4.6 & 8 & 742 & 3 & NA & 2.8 & $\begin{array}{l}\text { Cracking catalysts in petroleum refining, camera lenses, } \\
\text { battery electrodes, hydrogen storage, x-ray films. }\end{array}$ \\
\hline Dysprosium & 0.115 & 4.8 & NA & NA & 8 & 0.64 & $\begin{array}{l}\text { Motors or generators, wind turbines, and electrical } \\
\text { vehicles, hard disk devices, transducers. }\end{array}$ \\
\hline Yttrium & NA & NA & 100 & 18.5 & NA & NA & $\begin{array}{l}\text { Microwave generators, televisions and computer } \\
\text { screens, ceramics, superconductors. }\end{array}$ \\
\hline Platinum & 0.22 & 0.11 & 2.35 & 1.2 & NA & NA & Catalytic converters, electronic application, fuel cells \\
\hline Palladium & 0.22 & 0.11 & 2.35 & 1.1 & NA & NA & \\
\hline Lithium & 11.7 & 34 & 1006 & 8 & 1500 & 10.7 & Electric batteries, cordless devices, ceramics, glass. \\
\hline
\end{tabular}

NA: Not available 
Table 2: Composition of lithium in salt lake brine around the world

\begin{tabular}{|c|c|c|c|c|c|c|c|c|c|c|}
\hline \multirow[t]{2}{*}{ Source } & \multirow[t]{2}{*}{ Status } & \multicolumn{7}{|c|}{ Concentration (g/L) } & \multirow[t]{2}{*}{ Impurities } & \multirow[t]{2}{*}{ References } \\
\hline & & $\mathrm{Li}^{+}$ & $\mathrm{Mg}^{2+}$ & $\mathrm{Na}^{+}$ & $\mathrm{Ca}^{2+}$ & $\mathrm{K}^{+}$ & $\mathrm{B}$ & $\mathrm{SO}_{4}{ }^{2-}$ & & \\
\hline $\begin{array}{l}\text { Atacama Salar } \\
\text { Brine, Chile }\end{array}$ & Full-scale & 3.02 & 17.6 & 61.9 & 0.41 & 28.2 & 1.72 & 37.9 & $\mathrm{Na}^{+}, \mathrm{K}^{+}, \mathrm{Mg}^{2+}$ & Ogawa et al. (2014) \\
\hline $\begin{array}{l}\text { Uyuni Salar Brine, } \\
\text { Bolivia }\end{array}$ & & 0.84 & 16.7 & 105.4 & 3.33 & 15.7 & 0.7 & 21.3 & $\mathrm{Na}^{+}, \mathrm{K}^{+}, \mathrm{B}$ & An et al. (2012) \\
\hline $\begin{array}{l}\text { East Taijinar, } \\
\text { China }\end{array}$ & Pilot-scale & 0.14 & 5.64 & 117.03 & 0.43 & 3.79 & - & - & $\mathrm{Na}^{+}, \mathrm{K}^{+}$ & Sun et al. (2015) \\
\hline $\begin{array}{l}\text { West Taijinar, } \\
\text { China }\end{array}$ & & 0.26 & 15.36 & 102.4 & 0.19 & 8.44 & - & - & $\mathrm{Na}^{+}, \mathrm{K}^{+}$ & Sun et al. (2015) \\
\hline $\begin{array}{l}\text { Chott Djerid Salt } \\
\text { Lake, Tunisia }\end{array}$ & & 0.06 & 3.4 & 80 & 1.6 & 5.6 & - & 6.7 & $\begin{array}{l}\mathrm{Na}^{+}, \mathrm{Ca}^{2+}, \\
\mathrm{Mg}^{2+}\end{array}$ & Somrani et al. (2013) \\
\hline Longmucuo, China & & 1.21 & 89.5 & - & - & - & - & - & - & Song et al. (2017) \\
\hline $\begin{array}{l}\text { North Arm Salt } \\
\text { Lake, USA }\end{array}$ & Lab-scale & 0.04 & 9.38 & 100.8 & 0.35 & 5.5 & 0.03 & 19.7 & $\mathrm{Na}^{+}$ & Bush et al. (2016) \\
\hline $\begin{array}{l}\text { Salt lake brine, } \\
\text { China }\end{array}$ & & 0.35 & 113.7 & - & - & - & - & - & $\mathrm{Mg}^{2+}$ & Xiang et al. (2016) \\
\hline Salt lake brine & & 0.15 & 8.88 & 2.69 & - & - & - & - & - & Ji et al. (2017) \\
\hline Geothermal brine & & 0.01 & - & 0.11 & - & 0.16 & 0.03 & - & $\mathrm{K}^{+}$ & Mroczek et al. (2015) \\
\hline Synthetic brine & & 0.15 & 63.8 & 0.414 & 0.02 & 0.20 & & - & $\mathrm{Mg}^{2+}$ & Nie et al. (2017b) \\
\hline
\end{tabular}


Table 3: Examples of strategically important elements separation using membrane processes.

\begin{tabular}{|c|c|c|c|c|c|}
\hline Technology & Source & $\begin{array}{c}\text { Concentrate } \\
(\%)\end{array}$ & $\begin{array}{l}\text { Separated } \\
\text { elements }\end{array}$ & $\begin{array}{c}\text { Water } \\
\text { recovery (\%) }\end{array}$ & References \\
\hline \multirow[t]{8}{*}{ NF } & Salt lake & NA & Lithium & NA & Wen et al. (2006) \\
\hline & brine & & Lithium & & Somrani et al. (2013) \\
\hline & & & Lithium & & Sun et al. (2015) \\
\hline & Synthetic & NA & Lithium & NA & Zhang et al. (2017) \\
\hline & wastewater & & Cerium, & & Murthy and \\
\hline & & & Neodymium & & Choudhary (2012) \\
\hline & & & Neodymium & & Murthy and \\
\hline & & & & & Choudhary (2011) \\
\hline $\mathrm{RO}$ & $\begin{array}{l}\text { Salt lake } \\
\text { brine }\end{array}$ & NA & Lithium & NA & Somrani et al. (2013) \\
\hline \multirow[t]{3}{*}{ MD } & $\begin{array}{l}\text { Seawater } \\
\text { Brine }\end{array}$ & 500 & NA & 80 & Duong et al. (2015) \\
\hline & $\begin{array}{l}\text { Synthetic } \\
\text { brine }\end{array}$ & NA & Lithium & NA & $\begin{array}{l}\text { Quist-Jensen et al. } \\
\text { (2016b) }\end{array}$ \\
\hline & $\begin{array}{l}\text { Salt lake } \\
\text { brine }\end{array}$ & NA & Lithium & NA & Zhou (2017) \\
\hline \multirow[t]{7}{*}{ ED } & Salt lake & NA & Lithium & NA & Liu et al. (2015) \\
\hline & brine & & & & Jiang et al. (2014) \\
\hline & & & & & Ji et al. (2017) \\
\hline & $\begin{array}{l}\text { Geothermal } \\
\text { brine }\end{array}$ & NA & Lithium & NA & $\begin{array}{l}\text { Mroczek et al. } \\
\text { (2015) }\end{array}$ \\
\hline & Synthetic & NA & Lithium & NA & Nie et al. (2017b) \\
\hline & brine & & & & Bunani et al. (2017) \\
\hline & & & & & Parsa et al. (2015) \\
\hline
\end{tabular}

